\title{
Article \\ Principle of Least Effort and Sentence Length in Public Speaking
}

\author{
Natalia L. Tsizhmovska ${ }^{1}$ and Leonid M. Martyushev ${ }^{1,2, * \mathbb{D}}$ \\ 1 Technical Physics Department, Ural Federal University, 19 Mira St., 620002 Ekaterinburg, Russia; \\ n.1.tsizhmovska@urfu.ru \\ 2 Institute of Industrial Ecology, Russian Academy of Sciences, 20 S. Kovalevskaya St., \\ 620219 Ekaterinburg, Russia \\ * Correspondence: mlm@ecko.uran.ru or LeonidMartyushev@gmail.com; Tel.: +7-922-22-77425
}

Citation: Tsizhmovska, N.L.;

Martyushev, L.M. Principle of Least Effort and Sentence Length in Public Speaking. Entropy 2021, 23, 1023. https://doi.org/10.3390/ e23081023

Academic Editor: Matteo Convertino

Received: 19 July 2021

Accepted: 5 August 2021

Published: 8 August 2021

Publisher's Note: MDPI stays neutral with regard to jurisdictional claims in published maps and institutional affiliations.

Copyright: (c) 2021 by the authors. Licensee MDPI, Basel, Switzerland. This article is an open access article distributed under the terms and conditions of the Creative Commons Attribution (CC BY) license (https:// creativecommons.org/licenses/by/ $4.0 /)$.

\begin{abstract}
The analysis of sentence lengths in the inaugural speeches of US presidents and the annual speeches of UK party leaders is carried out. Transcripts of the speeches are used, rather than the oral production. It is discovered that the average sentence length in these speeches decreases linearly with time, with the slope of $0.13 \pm 0.03$ words/year. It is shown that among the analyzed distributions (log-normal, folded and half normal, Weibull, generalized Pareto, Rayleigh) the Weibull is the best distribution for describing sentence length. These two results can be considered a consequence of the principle of least effort. The connection of this principle with the well-known principles of maximum and minimum entropy production is discussed.
\end{abstract}

Keywords: quantitative linguistics; sentence lengths; principle of least effort; Weibull distribution; minimum entropy production principle

\section{Introduction}

The study of natural languages is extremely important not only for the human and social sciences, but also for the sciences that study the development patterns of complex systems (synergetics, cybernetics, etc.). An important section of language science is quantitative linguistics, which uses mathematical methods to establish language laws (note that the objectives and methods of quantitative linguistics go beyond the mere study of linguistic laws, see, e.g., [1,2]). At present, several similar laws are considered, and among them, the most famous are Zipf's law, Herdan's law, Brevity law, and Menzerath-Altmann's law [3-7]. Such laws, found mostly by statistical methods, indicate existing regularities between various elements of language (phonemes, words, etc.).

The most important element of language is the sentence-the object of this study. According to the Cambridge dictionary, a sentence is a group of words, usually containing a verb, that expresses a thought in the form of a statement, question, instruction, or exclamation. Sentences have semantic completeness; they express a particular thought of a person and serve to communicate it with other people. Based on the above sentence qualities, the study of these structural units is essential for cognitive science, which is of great interest. A metaphor from atomic physics would be very appropriate to illustrate this, especially for representatives of the natural sciences. Many properties of an atom are estimated by radiation (spontaneous and stimulated) that an atom emits and/or absorbs. A person (human brain) also "emits" and perceives elementary flows of thought in the form of sentences and the characteristics of this "human radiation" can reveal a lot about both the person and their environment.

An important quantitative characteristic of a sentence is its length, which can be measured in various ways (the number of letters, words, etc.). The study of sentence lengths does not require special linguistic training and can be easily processed by computer. As a result, this value has been studied for a long time and is used to determine the 
authorship of a work, the genre of the text, the cognitive development of the author or reader (listener), the level of language proficiency, etc. [8-14]. Two regularities are noticed regarding sentence length.

The first regularity is a decrease in the average sentence length over time. The decrease may vary depending on the genre and language of the text [15-18]. In particular, according to analysis of English texts [15]: "fiction sentences are approximately (on average) 6.5 words shorter now than they were in the beginning of the nineteenth century". The second regularity is the asymmetry of sentence length distribution in the text (their distribution functions are not normal). Various laws are proposed to describe sentence length distribution; log-normal is the most often, but it is also suggested to use others, in particular, gamma and hyperpascal distributions [4,6,19-24]. These regularities are associated with various factors; in particular, attempts are made to connect the log-normal distribution law with some stochastic multiplicative processes of sentence formation and the central limit theorem in logarithmic space [22]. There is no single general explanation of the noted regularities to date.

At the same time, the so-called principle of least effort [25] has existed for a long time in cognitive linguistics. According to this principle, language changes because speakers simplify their speech in various ways. This principle was suggested by G. Zipf. In 1949 he wrote: "a person, in solving his immediate problems, will view these against the background of his future problems, as estimated by himself. Moreover, he will strive to solve his problems in such a way as to minimize the total work that he must expend in solving both his immediate problems and his probable future problems. That in turn means that the person will strive to minimize the probable average rate of his work-expenditure (over time). And in so doing he will be minimizing his effort. Least effort, therefore, is a variant of least work." [25]. Note that G. Zipf is not the first to consider this kind of principle. In discussing the close connection between thinking and language, it is necessary to mention E. Mach and his principle of the economy of thought (1864): "when the human mind, with its limited powers, attempts to mirror in itself the rich life of the world, of which it itself is only a small part, and which it can never hope to exhaust, it has every reason for proceeding economically" [26].

Starting with G. Zipf, the discussed principle of least effort is used to explain the different frequencies of words of various lengths, the origins of scaling in human language, etc. (see, e.g., $[27,28])$. However, even at the sentence level, this principle from a single position allows us to explain the two above-mentioned regularities. In fact, languages have evolved so that language users can communicate using sentences that are relatively easy to produce and comprehend. It is worth quoting a fragment from Ref. [29] "Various models of human sentence production and comprehension predict that long dependencies are difficult or inefficient to process; minimizing dependency length thus enables effective communication without incurring processing difficulty". Thus, with a long-term observation of the language, sentence length will decrease. Let us consider the application of this principle for a significantly smaller timescale - creation time of the text by the author. The author strives to express each of his thoughts in the most economical, shortest way. As a result, the author consciously and unconsciously tends to use sentences of the minimum length $(L)$, among the variety of those that are similar in content $\left\{L_{1}, L_{2}, \ldots, L_{n}\right\}$, i.e., $L=\min \left\{L_{1}, L_{2}, \ldots, L_{n}\right\}$. It is well known from mathematical statistics $[30,31]$ that the distribution of the minima of a random variable corresponds to the Weibull distribution (strictly, if $L=\min \left\{L_{1}, L_{2}\right.$, $\left.\ldots, L_{n}\right\}, n \rightarrow \infty$ and $L_{1}, L_{2}, \ldots, L_{n}$ being identically distributed random variables equal to zero or larger, $L$ will obey the Weibull distribution function [30,31]). Thus, the principle of least effort unambiguously indicates that sentence lengths, with a sufficiently large sample, should be described by the Weibull distribution, and not by any other distributions. It is interesting to note that the Weibull distribution is a two-parameter asymmetric distribution that generalizes the well-known one-parameter Rayleigh distribution and can be reduced to a gamma distribution by changing the variable. 
The purpose of this work is to check the applicability of the Weibull distribution to the distribution of sentence lengths and to discover the law of the sentences length decrease over time. The results can provide additional justification for the applicability of the principle of least effort to elementary units of human speech that carry a particular thought.

\section{Data for Analysis}

The object of this research was to study the public speeches of politicians. Previously, this has beencarried out several times (see, e.g., [32-34]). However, the objectives of those studies were different from the objective of this work (readability and sentiment analysis, letter frequency distribution, etc.). Political speeches are a convenient object of research, since this is a form of oral speech that is well-documented for sufficiently long times. Political speeches are positioned between spoken and written ways of expressing thoughts. Unlike spoken speech, the speech under consideration is more meaningful, prepared ahead of time, and less spontaneous, from the speaker's point of view. At the same time, in comparison with written speech, political speeches are more focused on the listener, and, therefore, have a greater emotional component and the tendency to be easily understood. As a result, political speeches are extremely valuable research material. Such speeches are usually focused on some "average" citizen-the voter-therefore, the processing of such data reflects the temporal changes in the majority of native speakers.

We analyzed text transcripts of the 59 inaugural speeches of US presidents from 1789 to 2021 and 224 texts of speeches of UK Party leaders from 1895 to 2018 (available in [35] and [36], respectively). The studied speeches of US presidents are uniformly distributed every four years. The time distribution of speeches of UK Party leaders was not so uniform (due to copyright, the appearance of a new large party in parliament in 1977, etc.), but much more extensive. Note that no UK speeches were processed for 1898, 1914-1917, 1931, 1938-1940, 1944, 1952-1954, or1959. The list of analyzed speeches is presented in Appendixes.

Sentence length was calculated from period to period, the unit of measurement was the words between spaces (prior to analysis, we replace all question marks, exclamation marks, and ellipses with a period, and also remove all dots used when writing decimal numbers). Note that the selected unit of measure for sentence length is not exclusive. Words were selected as a unit of measure for sentence length primarily because of the simplicity and the great prevalence of this approach. It is necessary to note that according to [37], sentence length is robust with respect to the selection of the unit of measurement. Thus, the choice of the word (and, e.g., not letters) will not lead to a change in the results of further analysis. The calculation was carried out automatically using a developed and tested computer program (see, example in Figure 1).

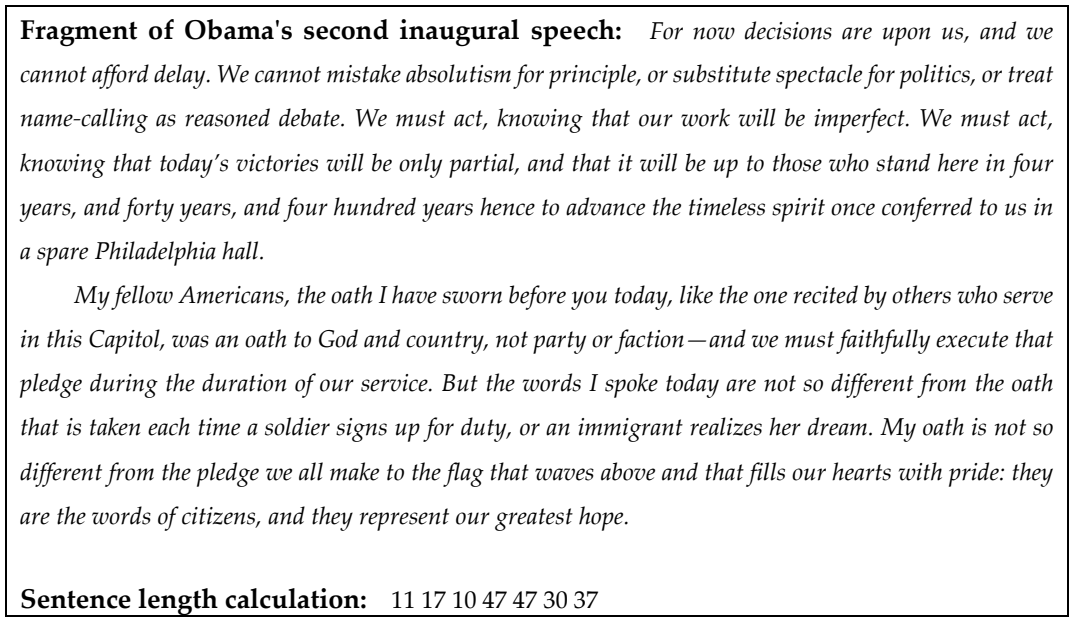

Figure 1. Example of sentence length calculation by the algorithm used in the study. 
Despite the fact that the studied speeches belonged to a long period of time, the total number of words in the speeches did not change reliably (Figure 2). The average length of speech in words was $2331 \pm 355$ for the US and $5434 \pm 774$ for the UK.

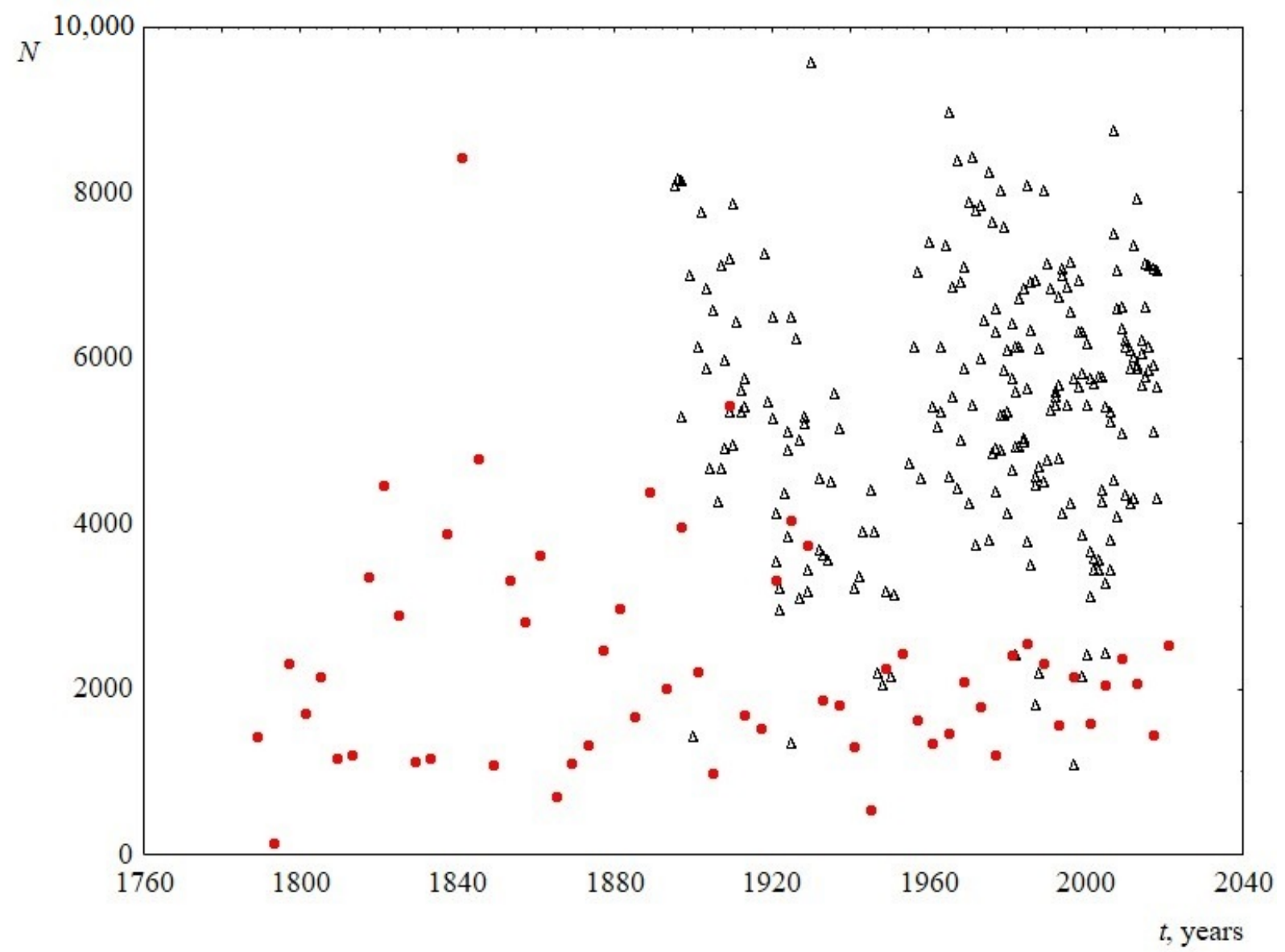

Figure 2. Number of words in the text $N$ versus time $t$. Red circles indicate data for USA, and black triangles indicate data for UK.

Statistical analysis was performed using the well-known and widespread professional commercial product Statistica 12.0 (TIBCO Software). The data (year of the speech and values corresponding to the processed sentence lengths of speeches) are in open access [38].

\section{Change in Sentence Length over Time}

The parameters characterizing sentence length were calculated. They are listed below.

1. The average sentence length. To calculate this parameter, the total number of words in a speech was divided by the number of sentences. The change in this parameter over time is shown in Figure 3. The figure demonstrates that the average sentence length decreases linearly, with the slopes for USA and UK practically coinciding, and are equal to $0.13 \pm 0.03$ and $0.14 \pm 0.01$, respectively. On average, over 100 years, from 1900 to 2000, the average sentence length for both sets decreases from 30 to 16 words in a sentence, that is, the length is reduced by almost twice. 


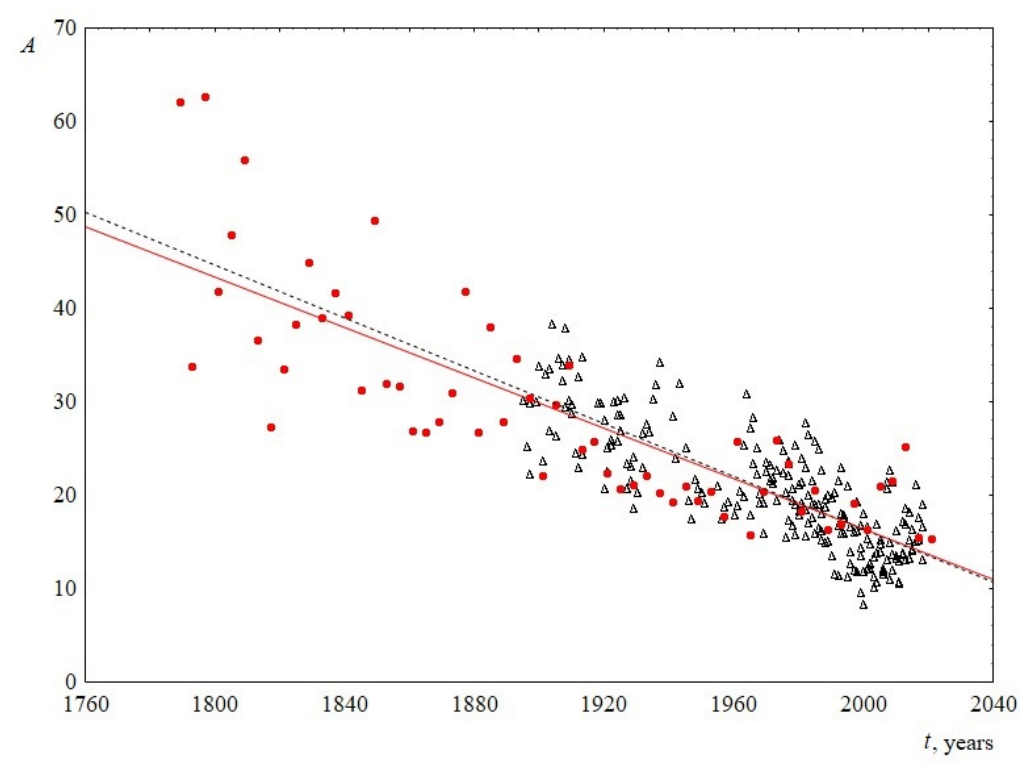

Figure 3. Average sentence length $A$ as a function of the time speaking $t$. Red circles indicate data for USA, and black triangles indicate data for UK. The linear regression equation for USA is $286-0.13 t$ and for UK is 299-0.14t.

2. The median is known to be a stable characteristic of the distribution, it is almost unaffected by outliers. According to Figure 4, the median sentence length distribution decreases linearly in both sets with time. The slopes of the lines for USA and UK are $0.11 \pm 0.02$ and $0.11 \pm 0.01$, respectively. It can be seen that the lines are very close and practically coincide with ones for average sentence lengths.

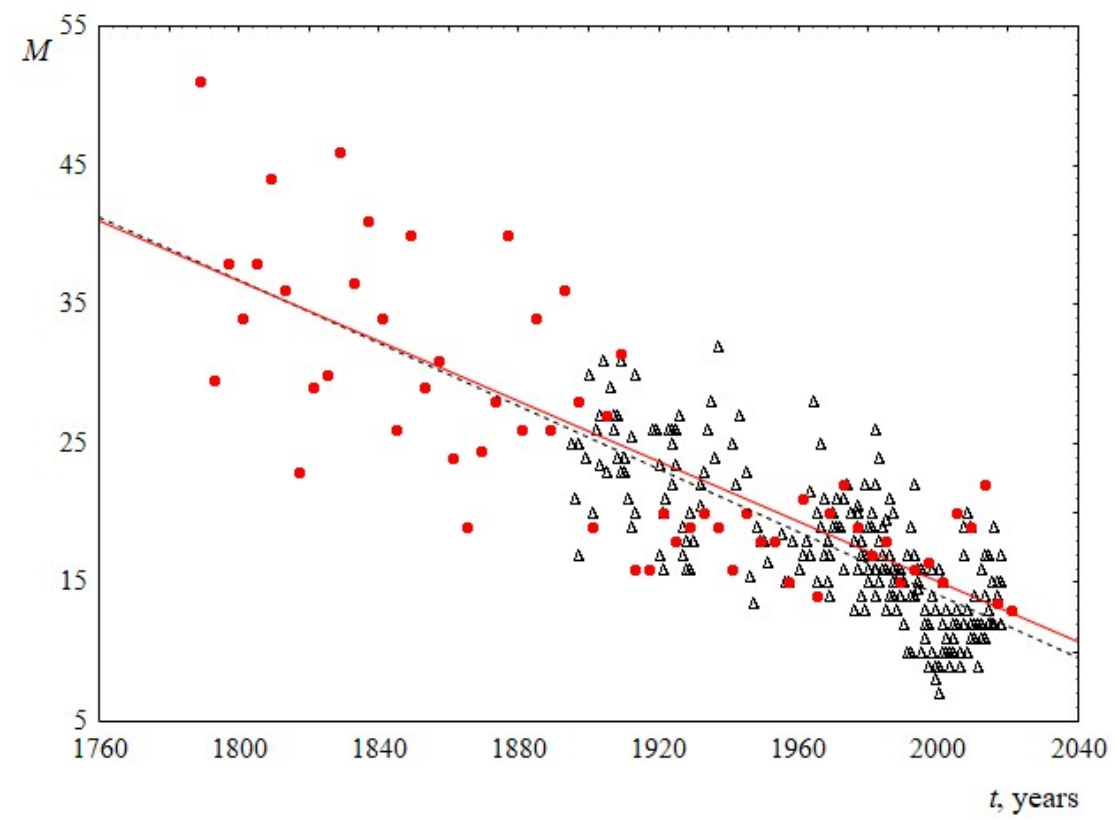

Figure 4. Median $M$ as a function of the time speaking $t$. Red circles indicate data for USA, and black triangles indicate data for UK. The linear regression equation for USA is $232-0.11 t$ and for UK is 240-0.11t.

3. The decrease in sentence length over time is also demonstrated in Figure 5, where the time dependence of the maximum sentence length is presented. The decrease in this parameter in both sets is approximately linear. 


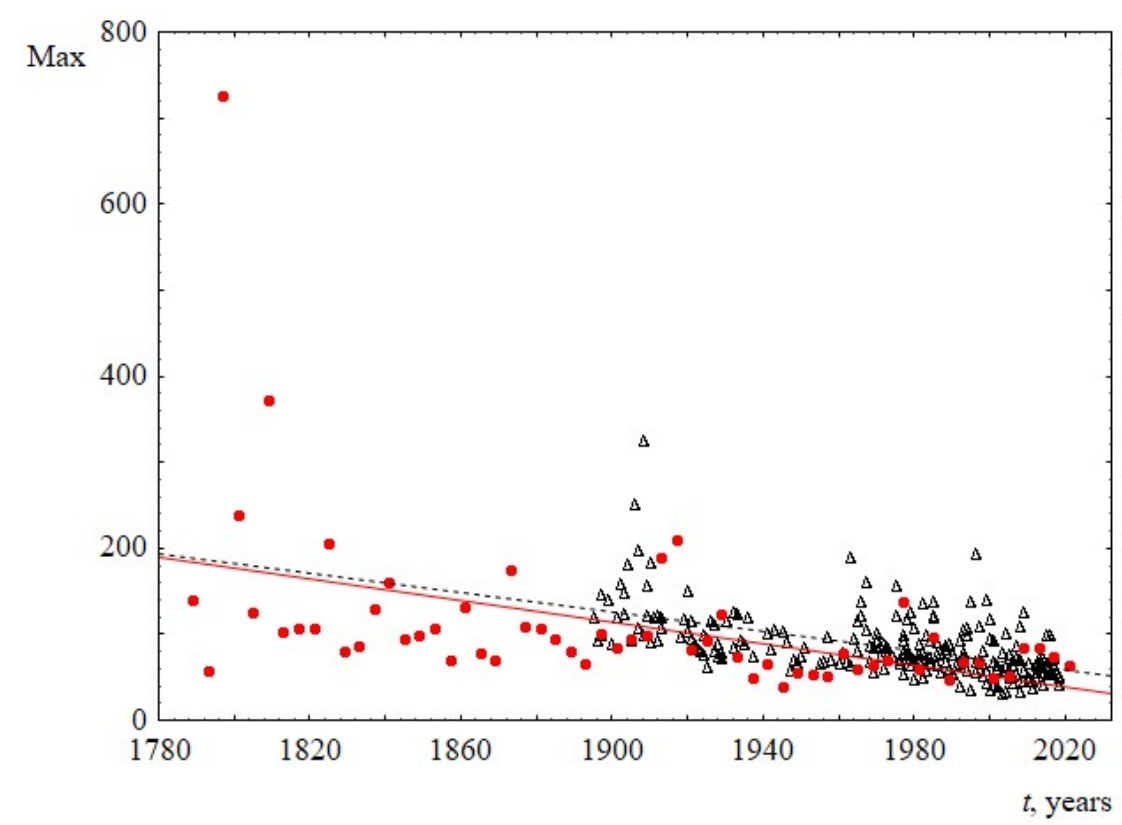

Figure 5. Maximum sentence length Max, as a function of the time speaking $t$. Red circles indicate data for USA, and black triangles indicate data for UK. The linear regression equation for USA is $1317-0.6 t$ with the slope of $0.6 \pm 0.3$. The linear regression equation for UK is $1197-0.6 t$ with the slope of $0.6 \pm 0.1$.

The final results of this section are summarized in Table 1.

Table 1. Time behavior of the average sentence length.

\begin{tabular}{ccc}
\hline \multirow{2}{*}{ Parameters Characterizing Sentence Length } & \multicolumn{2}{c}{ Linear Fitting, Confidence Level, Coefficient of Determination } \\
UK
\end{tabular}

\section{Analysis of the Sentence Length Distribution Law}

To analyze the sentence length distribution law, a number of speeches of the US presidents were excluded from the initial data. First, small speech texts, containing less than 40 sentences were excluded (these are speech texts of 1789, 1793, 1797, 1813, 1829, $1833,1849,1865,1869,1905$, and 1945). Second, since it is the texts of public oral speeches that are analyzed, the texts of 1953, 1961, 1973, and 1981 were excluded because these speeches were not spoken, but were only written. Third, speech texts of 1801, 1805, 1837, $1877,1881,1893,1941,1965$, and 1969 were not processed, since these speech texts have a multimodal distribution (the reasons for this and the analysis of these distributions could be the subject of a separate work). Thus, the analysis of the distribution law was carried out at 31 inaugural speeches of US presidents. All 224 speeches of the UK party leaders were analyzed. However, 31 texts were excluded due to the low significance level $(<0.05)$ of the results obtained in relation to all tested distribution laws. Single outliers were excluded from the datasets before data analysis.

Six distributions with no more than two parameters, such as log-normal, Weibull, folded normal, half normal (normal), generalized Pareto, Rayleigh were analyzed in order to find the best theoretical distribution that describes the studied empirical distributions. The ranking of these distributions by the quality of data description was carried out according to the Kolmogorov-Smirnov criterion: the larger the $p$-level value, the better this distribution describes the empirical data and, accordingly, the higher its place in compari- 
son with others. Tables 2 and 3 show the number of times one of the six listed sentence length distributions was among the top three (see Appendix A for more information).

Table 2. Ranking of distributions according to the Kolmogorov-Smirnov criterion. US speeches.

\begin{tabular}{cccccccc}
\hline & & Weibull & Log-Normal & Rayleigh & Folded Normal & Normal & General Pareto \\
\hline \multirow{2}{*}{ Place } & 1 & 14 & 13 & 3 & 1 & 0 & 0 \\
& 2 & 14 & 5 & 6 & 4 & 1 & 0 \\
& 3 & 3 & 1 & 9 & 8 & 8 & 1 \\
\hline$\sum$ & 31 & 19 & 18 & 13 & 9 & 1 \\
\hline
\end{tabular}

Table 3. Ranking of distributions according to the Kolmogorov-Smirnov criterion. UK speeches.

\begin{tabular}{cccccccc}
\hline & & Weibull & Log-Normal & Rayleigh & Folded Normal & Normal & General Pareto \\
\hline \multirow{3}{*}{ Place } & 1 & 144 & 62 & 4 & 2 & 1 & 1 \\
& 2 & 47 & 43 & 27 & 23 & 8 & 0 \\
& 3 & 2 & 20 & 14 & 16 & 19 & 0 \\
\hline$\Sigma$ & 193 & 125 & 45 & 41 & 28 & 1 \\
\hline
\end{tabular}

Table 2 shows that, in 14 inaugural speeches of the US presidents, the Weibull distribution took first place in terms of significance, in another 14 it took second place, and in 3, it took third place. Thus, the Weibull distribution is the only distribution that adequately describes all speeches and takes the top three places. The average distribution significance level, where Weibull was in the first place, is 0.73 , and for the second and third places, it is 0.5 and 0.3 , respectively (see Appendix A). The log-normal distribution, ranked in the top three for 19 speeches, describes the data somewhat worse than Weibull one. The average significance levels for the log-normal distribution are 0.67 for the first place (13 speeches), 0.37 for the second place ( 5 speeches) and 0.08 for the third place $(1$ speech). Similar results can be seen for UK speeches (see Table 3 and Appendix A).

Thus, according to the performed statistical analysis, the Weibull distribution is the most preferable for describing the studied speeches. The Weibull distribution (cumulative distribution function) has the form $1-\exp \left(-(\mathrm{x} / \lambda)^{\mathrm{k}}\right)$, where $\lambda$ and $\mathrm{k}$ are the scale and shape parameters respectively. Examples of the experimental data description using the Weibull distribution are presented in Figure 6. Note that the one-parameter Rayleigh distribution, ranked third in the description quality according to the analysis results, is a special case of the Weibull distribution, where the shape parameter is equal to two (see Tables 2 and 3).

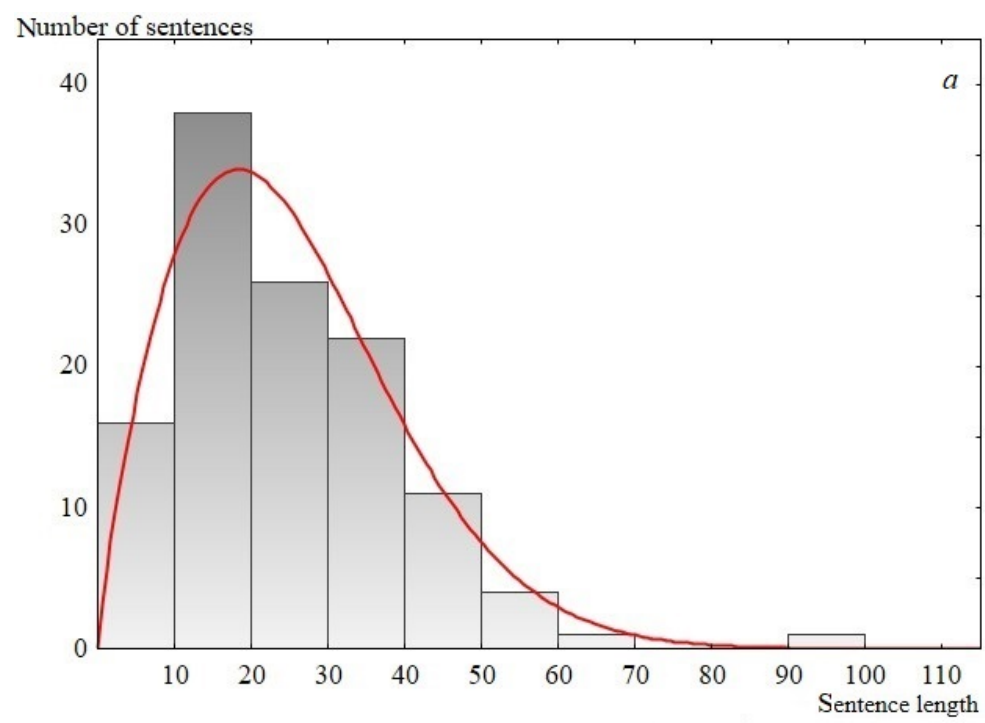

Figure 6. Cont. 


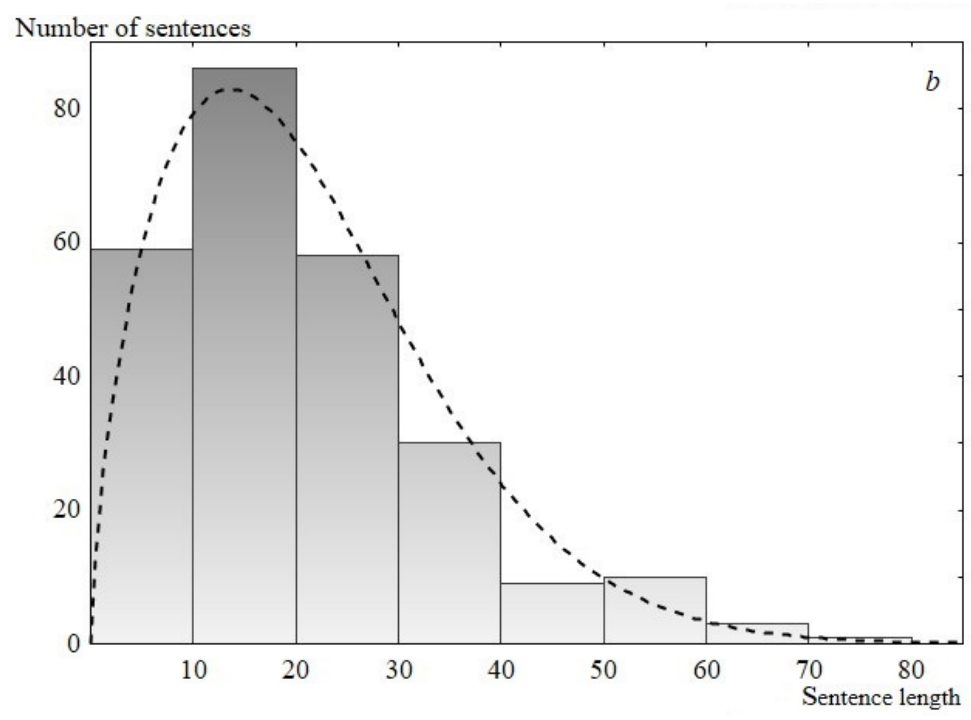

Figure 6. Sentence length distribution histogram. (a) USA speech, 1817; 119 points. The solid line is the Weibull distribution, for which p-level is 0.80, $\lambda=28.4$ and $k=1.8$; (b) UK Labour Party, 1992; 256 points. The dashed line is the Weibull distribution, for which p-level is $0.42, \lambda=23.8$ and $k=1.7$.

The behavior of the parameters of the Weibull distribution over time is shown in Figures 7 and 8 (see Appendix B for numerical details). It follows from the Figure 7 that the scale parameter reliably decreases over time. Since this parameter is known to be directly proportional to the mean, median, and mode of the Weibull distribution, this once again confirms the above statement about the decrease in the average (and the most probable) sentence length. The shape parameter for US speeches does not reliably change over time and is equal to $1.9 \pm 0.1$. At the same time, the shape parameter for UK speeches is slightly increasing, changing from 1.5 to 1.8 over the past 100 years. This is the only difference found when comparing sentence lengths for US and UK speeches. Since the change over time is not large (the slope of the line is $0.002 \pm 0.001$ ), for reliability, an analysis of this result using additional data is required. Table 4 summarizes the results on the behavior of the parameters of the Weibull distribution over time.

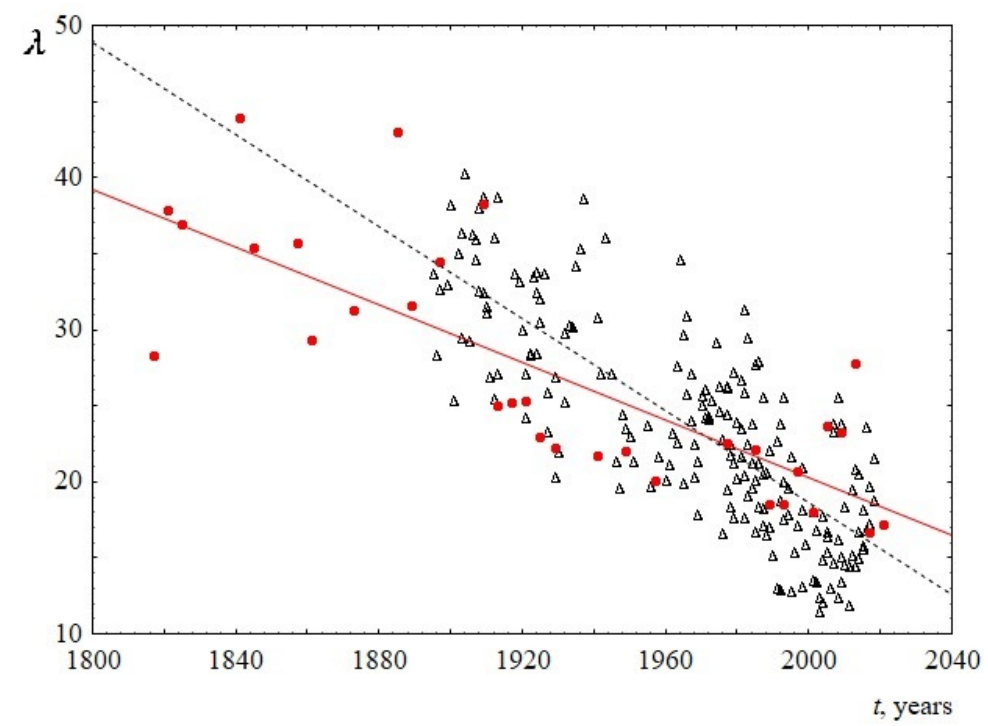

Figure 7. Behavior of the scale parameter $\lambda$ of the Weibull distribution versus the time $t$. Red circles indicate data for USA, and black triangles indicate data for UK. The linear regression equation for USA is $209.8-0.09 t$ with the slope of $0.09 \pm 0.03$. The linear regression equation for UK is $321.5-0.15 t$ with the slope of $0.15 \pm 0.02$. 


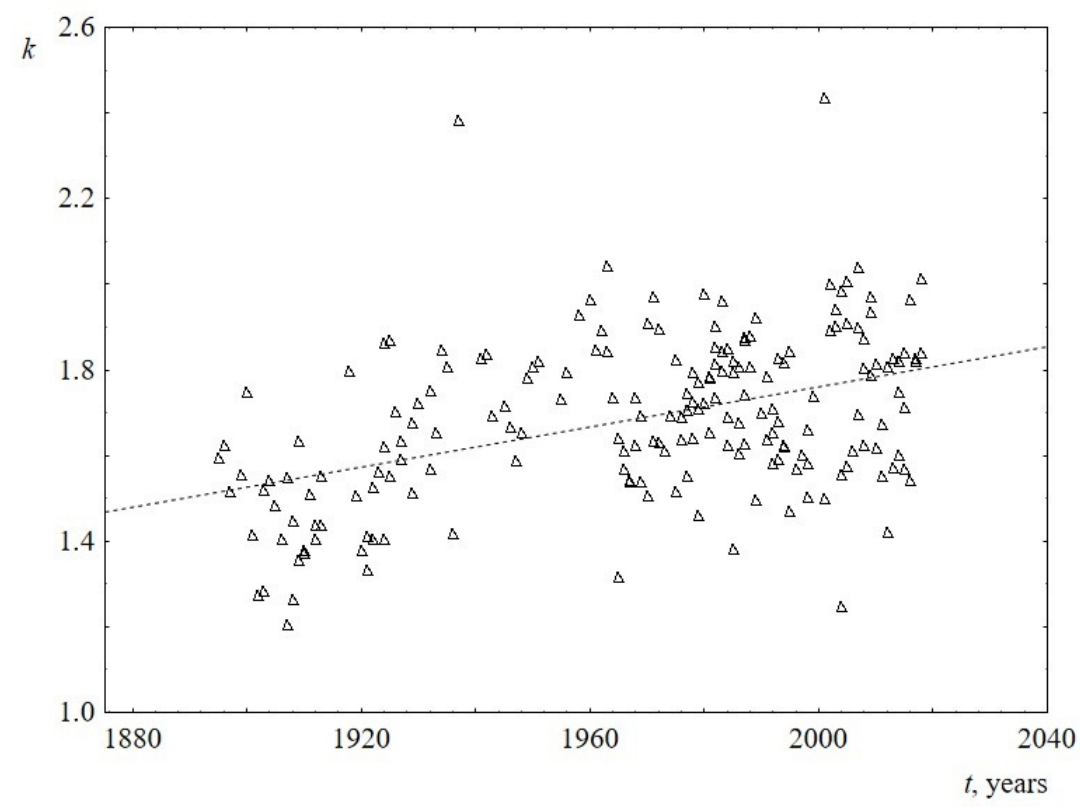

Figure 8. Behavior of the shape parameter $k$ of the Weibull distribution versus the time $t$ for UK. The linear regression equation is $-2.9+0.002 t$ (the slope of the line is $0.002 \pm 0.001$ ).

Table 4. Parameters of the Weibull distribution for USA and UK speeches.

\begin{tabular}{ccc}
\hline Parameters of the Weibull Distribution & Linear Fitting, Confidence Level, Coefficient of Determination & UK \\
\hline Scale $(\lambda)$ & $209.8-(0.09 \pm 0.03) t, 95 \%, 0.63$ & $321.5-(0.15 \pm 0.02) t, 95 \%, 0.64$ \\
Shape $(k)$ & $1.9 \pm 0.1,95 \%$ & $-2.9+(0.002 \pm 0.001) t, 95 \%, 0.19$ \\
\hline
\end{tabular}

Thus, the time behavior of the parameters of the Weibull distribution allows us to conclude that, over the past two hundred years, sentence length distribution has become less fuzzy, the width of the peak decreases, and its abscissa is slightly shifted to the left. This is demonstrated in Figure 9. As a result, over time, speeches become composed of similar in length and shorter sentences, the difference in length decreases. In terms of sentence lengths, the text becomes more ordered. This can be seen in Figure 10, where information entropy (Shannon entropy) is presented as a function of time. The calculation of this value was based on sentence length distribution histograms containing the probabilities of detecting sentence length in a speech at a certain length interval. 

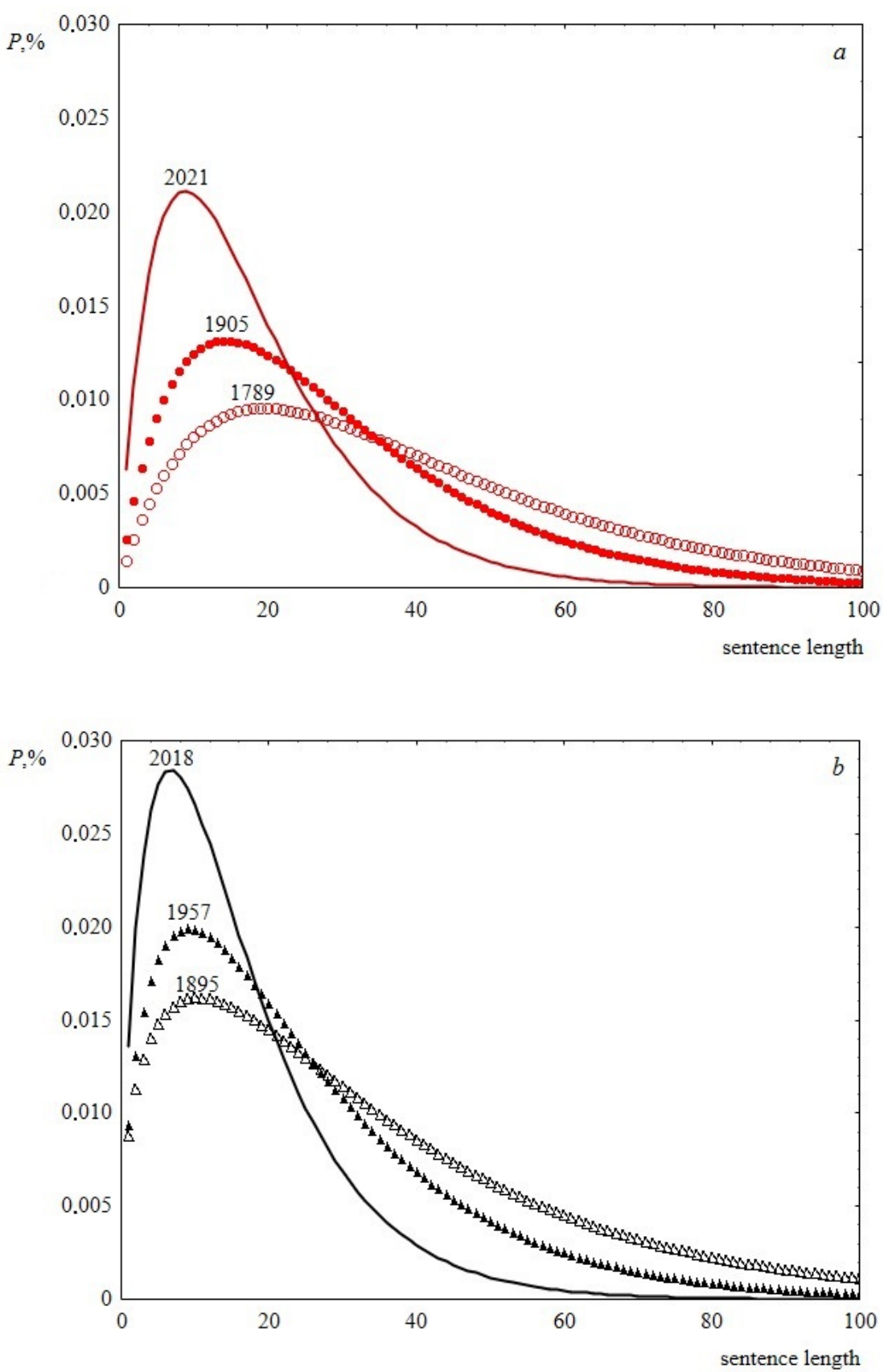

Figure 9. Weibull distribution histograms showing the change in sentence length distributions over time. (a) Data for USA, the shape parameter is 1.9, the scale parameters are 40.2, 29.2 and 18.2 for 1789, 1905 and 2021, respectively. (b) Data for UK, the shape parameters are 1.4, 1.6, 1.7 and the scale parameters are 34.6, 25.2 and 15.9 for 1895,1957 and 2018, respectively. 


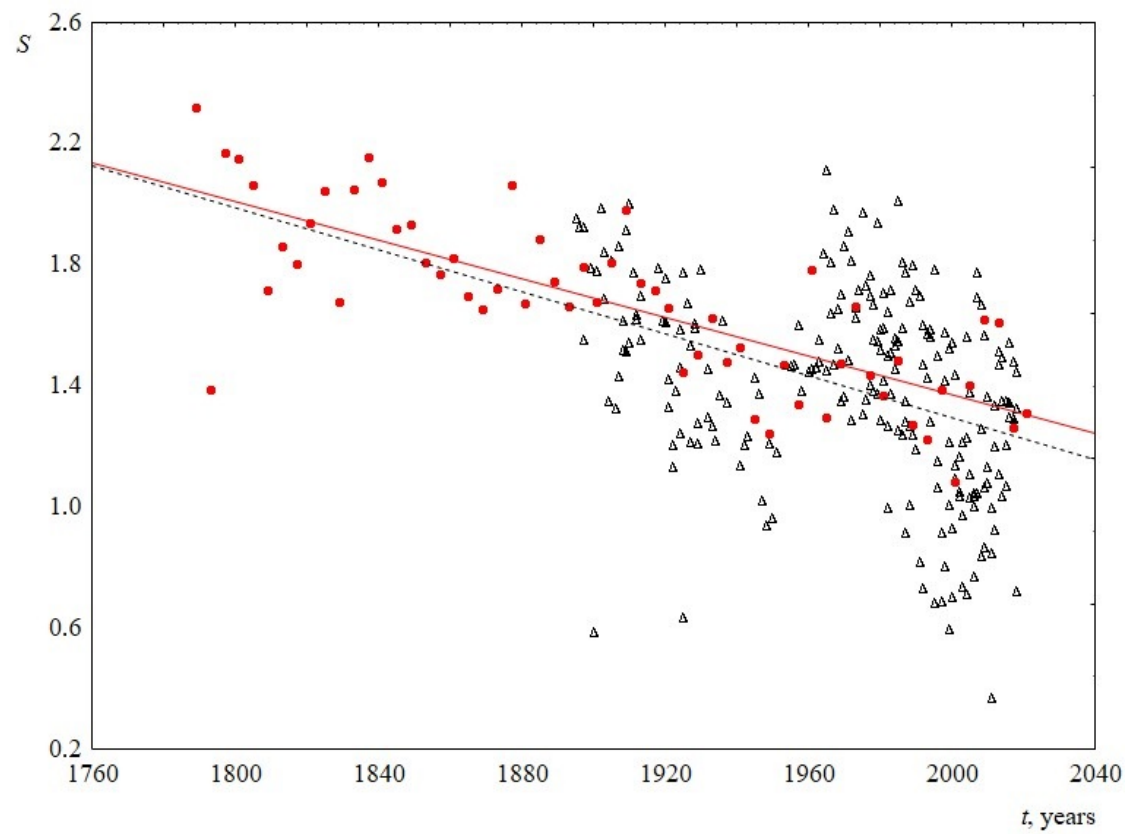

Figure 10. Information entropy $S$ versus the time $t$. Red circles indicate data for USA, and black triangles indicate data for UK. The linear regression equation for USA is 7.7-0.003t (the slope of the line is $0.003 \pm 0.001$ ) and for UK is $8.2-0.003 t$ (the slope of the line is $0.003 \pm 0.001$ ).

\section{Conclusions}

Based on the calculation of sentence lengths in the text transcripts of the inaugural speeches of the US presidents for 228 years and the annual speeches of the UK party leaders for 123 years, two main results were obtained:

1. The average sentence length for both US and UK speeches decreases linearly with time with the slope of $0.13 \pm 0.03$ words/year and, on average, from 1900 to 2000, sentence length decreased with time from 30 to 16 words.

2. Sentence length distribution for both US and UK speeches is better described by the Weibull distribution (in particular, in comparison with the log-normal). The scale parameter of this distribution reliably decreases over time from 35 to 15 . The shape parameter for US speeches does not change over time and is equal to $1.9 \pm 0.1$, and the shape parameter for UKspeeches slightly changes over time from 1.5 to 1.8 .

These two results are in agreement with the principle of least effort: the speaker, attempting to minimize both their efforts and the listeners' effort, tends to choose the shortest possible sentence length from a potential set of sentences of approximately the same content. As a result, on the one hand, sentence length distribution begins to correspond to the distribution of minimum values - the Weibull distribution, and on the other hand, at time intervals significantly longer than the speech preparation time, the average sentence length decreases. The detected change over time in the scale parameter of the Weibull distribution and in information entropy indicates that sentence length in public speeches is gradually becoming less diverse; it is being unified and standardized.

Here we highlight the following idea. When establishing the distribution type for empirical data, most important are not statistical tests, but rather the theoretical justification. If we accept the principle of least effort, then the Weibull distribution clearly follows from it. If one assumes that the principle of least effort is not suitable here, then obviously, they must propose some other theoretical justification - their principle - and theoretically derive, for example, gamma or lognormal distributions from it. Currently, we do not see such attempts. The G. Zipf's principle, in our opinion, is very profound and productive, and many interesting consequences can be obtained from it. It has great potential, which has not yet been fully embraced by modern linguists. Our work and a number of works (see, e.g., $[27,28,39-43]$ ) show how useful it can be. 
An interesting continuation of this work can be the verification of the obtained results using breath groups [6]. Detecting correlations and differences in such a collaborative analysis of breath groups (largely related to human physiology) and sentence lengths (largely related to cognitive processes) is a very interesting task. One of the problems in this direction will be a significantly smaller statistical database for breath groups in comparison with an almost limitless database for sentence lengths. Another interesting development of this work, in the scope of currently well-established directions connected to language complex networks (see, e.g., [39-43]), could be an analysis of the data obtained, here, from the position of the principle of compression, which appeared as a development of the ideas of G. Zipf [43]. It seems to us that the results of this work, combined with the principle of compression and with the use of Kolmogorov complexity ideas (existing inalgorithmic information theory) could be very promising. Found patterns for English also require validation for other languages, including artificial, as well as using other methods and linguistic units (letters, initial characters, words, etc.). In this regard, works [44-46] may be useful.

In conclusion, we return to the metaphor from physics given in the introduction. The analysis of the atom emission spectra and the Planck formula for wavelength distribution revolutionized the understanding of atomic properties, leading to the formulation of the laws of the quantum world - quantum mechanics. The distribution law of the lengths of utterances (sentences) "emitted" by the brain, corresponding to the Weibull distribution, is also able to stimulate the development of brain sciences. One of the possible directions related to brain biophysics may be the study of the energetic basis of the origin and development of thought and language. There are a number of works in this direction, in particular [4,6,47-53]. Considering thought as a complex non-equilibrium process, it can be concluded that its development matches the well-known principle of maximum entropy production. According to this principle, causes (stimuli) generate such responses that maximize the thermodynamic entropy production $[47,54,55]$. One of these responses in the course of the evolution of human thinking was the origin of the language. This revolutionary bifurcation process led to an abrupt increase in energy consumption and, as a result, an increase in the entropy production in a nonequilibrium system, i.e., in neural networks of humans who have become users of language. Naturally, a spontaneously emerged structure (network) could not be optimal at inception: only a certain basic structure (framework) of language was formed, which had some imperfections. Subsequently, being already at the high level of energy consumption and entropy production achieved after bifurcation, the nonequilibrium system began to evolve for a rather long time, trying to minimize energy consumption $[54,55]$. This minimization will no longer return the system to its previous, pre-bifurcation values of entropy production; however, due to the optimization of the neural network processes responsible for language, a small decrease is possible. According to nonequilibrium thermodynamics, this optimization process is already progressing in accordance with the Prigogine minimum production principle $[47,54,55]$. Its linguistic analogue can be considered the principle of least effort (least effort assumes less energy spent on communication, and, consequently, less energy dissipation). The information on the "simplification" of language-a decrease in its entropy, discovered in this work, can be considered a confirmation that language is currently going through a second (minimizing) stage of development.

Author Contributions: L.M.M.: Conceptualization, Methodology, Supervision, Investigation, Writingoriginal draft, Writing - review and editing. N.L.T.: Investigation, Software, Validation, Computation, Visualization, Reading-review and editing. All authors have read and agreed to the published version of the manuscript.

Funding: This research received no external funding.

Institutional Review Board Statement: Not applicable.

Informed Consent Statement: Not applicable.

Data Availability Statement: Not applicable. 
Conflicts of Interest: The authors declare no conflict of interest.

\section{Appendix A}

Ranking the suitability of theoretical distribution laws for the observed empirical sentence length distributions based on the Kolmogorov-Smirnov criterion. After the name of the distribution, its $p$-level is given:

DATA FOR USA

\begin{tabular}{|c|c|c|c|}
\hline Year & I Place, $p$-Value & II Place, $p$-Value & III Place, $P$-Value \\
\hline 1817 & Weibull, 0.80 & Log Normal, 0.52 & Rayleigh, 0.33 \\
\hline 1821 & Log Normal, 0.51 & Weibull, 0.41 & Rayleigh, 0.20 \\
\hline 1825 & Log Normal, 0.97 & Weibull, 0.79 & Folded Normal, 0.56 \\
\hline 1841 & Log Normal, 0.98 & Weibull, 0.38 & Rayleigh, 0.10 \\
\hline 1845 & Log Normal, 0.72 & Weibull, 0.30 & Rayleigh, 0.02 \\
\hline 1857 & Folded Normal, 0.97 & Weibull, 0.96 & Normal, 0.90 \\
\hline 1861 & Weibull, 0.91 & Log Normal, 0.45 & Normal, 0.16 \\
\hline 1873 & Rayleigh, 0.86 & Weibull, 0.85 & Folded Normal, 0.62 \\
\hline 1885 & Weibull, 0.80 & Folded Normal, 0.66 & Normal, 0.59 \\
\hline 1889 & Rayleigh, 0.54 & Weibull, 0.54 & Folded Normal, 0.24 \\
\hline 1897 & Weibull, 0.57 & Log Normal, 0.52 & Rayleigh, 0.49 \\
\hline 1909 & Weibull, 0.97 & Rayleigh, 0.72 & Folded Normal, 0.68 \\
\hline 1913 & Log Normal, 0.54 & Weibull, 0.18 & Half Normal, 0.12 \\
\hline 1917 & Log Normal, 0.85 & Weibull, 0.30 & Half Normal, 0.12 \\
\hline 1921 & Weibull, 0.43 & Log Normal, 0.18 & Rayleigh, 0.06 \\
\hline 1925 & Rayleigh, 0.25 & Weibull, 0.20 & Log Normal, 0.08 \\
\hline 1929 & Weibull, 0.26 & Rayleigh, 0.13 & Folded Normal, 0.03 \\
\hline 1941 & Log Normal, 0.75 & Weibull, 0.73 & Folded Normal, 0.17 \\
\hline 1949 & Log Normal, 0.54 & Weibull, 0.54 & Folded Normal, 0.19 \\
\hline 1957 & Log Normal, 0.56 & Rayleigh, 0.26 & Weibull, 0.24 \\
\hline 1977 & Weibull, 0.90 & Rayleigh, 0.75 & Normal, 0.65 \\
\hline 1985 & Log Normal, 0.40 & Weibull, 0.22 & Rayleigh, 0.09 \\
\hline 1989 & Log Normal, 0.72 & Rayleigh, 0.5 & Weibull, 0.49 \\
\hline 1993 & Weibull, 0.89 & Folded Normal, 0.59 & Rayleigh, 0.54 \\
\hline 1997 & Log Normal, 0.41 & Rayleigh, 0.20 & Weibull, 0.18 \\
\hline 2001 & Weibull, 0.45 & Log Normal, 0.19 & Folded Normal, 0.18 \\
\hline 2005 & Weibull, 0.92 & Folded Normal, 0.56 & Normal, 0.53 \\
\hline 2009 & Weibull, 0.97 & Half Normal, 0.23 & General Pareto, 0.16 \\
\hline 2013 & Log Normal, 0.75 & Weibull, 0.63 & Rayleigh, 0.60 \\
\hline 2017 & Weibull, 0.71 & Folded Normal, 0.51 & Normal, 0.33 \\
\hline 2021 & Weibull, 0.67 & Log Normal, 0.31 & Folded Normal, 0.01 \\
\hline \multicolumn{4}{|l|}{ DATA FOR UK } \\
\hline Year, Party & I Place, $p$-Value & II Place, $p$-Value & III Place, $p$-Value \\
\hline 1895 Liberal & Log Normal, 0.37 & Weibull, 0.37 & Folded Normal, 0.01 \\
\hline 1896 Liberal & Log Normal, 0.46 & Weibull, 0.28 & Normal, 0.00 \\
\hline 1897 Liberal & Log Normal, 0.06 & Weibull, 0.01 & Half Normal, 0.00 \\
\hline 1897 Conservative & Weibull, 0.47 & Log Normal, 0.22 & Half Normal, 0.02 \\
\hline 1899 Liberal & Weibull, 0.29 & Log Normal, 0.15 & Normal, 0.00 \\
\hline 1900 Conservative & Weibull, 0.87 & Folded Normal, 0.64 & Log Normal, 0.57 \\
\hline 1901 Liberal & Weibull, 0.31 & Log Normal, 0.07 & Half Normal, 0.05 \\
\hline 1902 Conservative & Folded Normal, 0.46 & Half Normal, 0.46 & Weibull, 0.30 \\
\hline 1903 Conservative & Weibull, 0.84 & Half Normal, 0.39 & Log Normal, 0.26 \\
\hline 1903 Liberal & Weibull, 0.51 & Folded Normal, 0.08 & Normal, 0.06 \\
\hline 1904 Conservative & Weibull, 0.64 & Folded Normal, 0.42 & General Pareto, 0.18 \\
\hline 1905 Liberal & Weibull, 0.18 & Log Normal, 0.14 & Half Normal, 0.01 \\
\hline
\end{tabular}




\begin{tabular}{|c|c|c|c|}
\hline Year, Party & I Place, $p$-Value & II Place, $p$-Value & III Place, $p$-Value \\
\hline 1906 Conservative & Half Normal, 0.37 & Weibull, 0.36 & General Pareto, 0.23 \\
\hline 1907 Conservative & General Pareto, 0.25 & Weibull, 0.16 & Log Normal, 0.13 \\
\hline 1907 Liberal & Weibull, 0.53 & Half Normal, 0.13 & Normal, 0.09 \\
\hline 1908 Liberal & Weibull, 0.59 & Folded Normal, 0.13 & Half Normal, 0.13 \\
\hline 1908 Conservative & Weibull, 0.66 & Log Normal, 0.45 & Half Normal, 0.27 \\
\hline 1909 Liberal & Weibull, 0.69 & Folded Normal, 0.3 & Log Normal, 0.05 \\
\hline 1909 Conservative & Weibull, 0.34 & Log Normal, 0.34 & Half Normal, 0.16 \\
\hline 1910 Liberal & Weibull, 0.38 & Folded Normal, 0.27 & Half Normal, 0.26 \\
\hline 1910 Conservative & Weibull, 0.92 & Half Normal, 0.24 & Folded Normal, 0.24 \\
\hline 1911 Conservative & Weibull, 0.72 & Log Normal, 0.13 & Folded Normal, 0.07 \\
\hline 1912 Liberal & Weibull, 0.55 & Log Normal, 0.3 & Folded Normal, 0.21 \\
\hline 1912 Conservative & Weibull, 0.17 & Log Normal, 0.14 & Half Normal, 0.03 \\
\hline 1913 Conservative & Log Normal, 0.11 & Weibull, 0.07 & Half Normal, 0.02 \\
\hline 1913 Liberal & Weibull, 0.91 & Log Normal, 0.28 & Folded Normal, 0.26 \\
\hline 1918 Liberal & Weibull, 0.82 & Rayleigh, 0.17 & Log Normal, 0.07 \\
\hline 1919 Liberal & Weibull, 0.98 & Half Normal, 0.12 & Log Normal, 0.09 \\
\hline 1920 Liberal & Weibull, 0.66 & Folded Normal, 0.65 & Half Normal, 0.62 \\
\hline 1920 Conservative & Weibull, 0.02 & Log Normal, 0.02 & Folded Normal, 0.01 \\
\hline 1921 Liberal & Weibull, 0.67 & Log Normal, 0.63 & Half Normal, 0.23 \\
\hline 1921 Conservative & Log Normal, 0.58 & Weibull, 0.09 & Half Normal, 0.07 \\
\hline 1922 Liberal & Weibull, 0.90 & Half Normal, 0.73 & General Pareto, 0.51 \\
\hline 1922 Conservative & Weibull, 0.52 & Log Normal, 0.48 & Folded Normal, 0.10 \\
\hline 1923 Liberal & Weibull, 0.85 & General Pareto, 0.25 & Normal, 0.15 \\
\hline 1924 Liberal & Log Normal, 0.85 & Weibull, 0.50 & Folded Normal, 0.26 \\
\hline 1924 Labour & Weibull, 0.77 & Half Normal, 0.24 & Folded Normal, 0.24 \\
\hline 1924 Conservative & Weibull, 0.75 & Log Normal, 0.39 & Folded Normal, 0.11 \\
\hline 1925 Liberal & Log Normal, 0.83 & Weibull, 0.60 & Rayleigh, 0.33 \\
\hline 1925 Conservative & Weibull, 0.47 & Log Normal, 0.02 & Normal, 0.02 \\
\hline 1926 Conservative & Weibull, 0.21 & Log Normal, 0.09 & Rayleigh, 0.01 \\
\hline 1927 Liberal & Log Normal, 0.67 & Weibull, 0.21 & Folded Normal, 0.01 \\
\hline 1927 Conservative & Log Normal, 0.47 & Weibull, 0.19 & Folded Normal, 0.01 \\
\hline 1928 Liberal & Log Normal, 0.35 & Weibull, 0.04 & Half Normal, 0.00 \\
\hline 1928 Conservative & Log Normal, 0.45 & Weibull, 0.01 & Folded Normal, 0.00 \\
\hline 1929 Liberal & Log Normal, 0.37 & Weibull, 0.19 & Folded Normal, 0.03 \\
\hline 1929 Conservative & Log Normal, 0.67 & Weibull, 0.61 & Folded Normal, 0.05 \\
\hline 1930 Liberal & Weibull, 0.16 & Log Normal, 0.00 & Normal, 0.00 \\
\hline 1932 Conservative & Weibull, 0.78 & Log Normal, 0.23 & Normal, 0.10 \\
\hline 1932 Liberal & Log Normal, 0.52 & Weibull, 0.45 & Folded Normal, 0.03 \\
\hline 1933 Conservative & Log Normal, 0.70 & Weibull, 0.57 & Folded Normal, 0.08 \\
\hline 1934 Conservative & Weibull, 0.75 & Folded Normal, 0.72 & Normal, 0.67 \\
\hline 1935 Conservative & Weibull, 0.61 & Folded Normal, 0.53 & Rayleigh, 0.32 \\
\hline 1936 Liberal & Log Normal, 0.89 & Weibull, 0.19 & Folded Normal, 0.03 \\
\hline 1937 Liberal & Weibull, 0.74 & Folded Normal, 0.46 & Log Normal, 0.41 \\
\hline 1941 Liberal & Weibull, 0.68 & Log Normal, 0.54 & Rayleigh, 0.43 \\
\hline 1942 Liberal & Weibull, 0.67 & Rayleigh, 0.38 & Log Normal, 0.31 \\
\hline 1943 Liberal & Log Normal, 0.74 & Weibull, 0.51 & Normal, 0.07 \\
\hline 1945 Liberal & Weibull, 0.62 & Rayleigh, 0.23 & Normal, 0.11 \\
\hline 1946 Labour & Log Normal, 0.29 & Weibull, 0.08 & Normal, 0.00 \\
\hline 1947 Labour & Log Normal, 0.76 & Weibull, 0.21 & Normal, 0.01 \\
\hline 1948 Labour & Log Normal, 0.85 & Weibull, 0.51 & Normal, 0.04 \\
\hline 1949 Labour & Weibull, 0.47 & Log Normal, 0.38 & Folded Normal, 0.08 \\
\hline 1950 Labour & Log Normal, 0.55 & Weibull, 0.39 & Normal, 0.11 \\
\hline 1951 Labour & Log Normal, 0.85 & Weibull, 0.19 & Rayleigh, 0.02 \\
\hline 1955 Conservative & Weibull, 0.32 & Log Normal, 0.29 & Rayleigh, 0.03 \\
\hline
\end{tabular}




\begin{tabular}{|c|c|c|c|}
\hline Year, Party & I Place, $p$-Value & II Place, $p$-Value & III Place, $p$-Value \\
\hline 1956 Conservative & Weibull, 0.11 & Log Normal, 0.07 & Folded Normal, 0.01 \\
\hline 1957 Conservative & Log Normal, 0.38 & Weibull, 0.05 & Folded Normal, 0.00 \\
\hline 1958 Conservative & Log Normal, 0.15 & Weibull, 0.13 & Rayleigh, 0.09 \\
\hline 1960 Conservative & Weibull, 0.53 & Rayleigh, 0.35 & Folded Normal, 0.03 \\
\hline 1961 Conservative & Weibull, 0.68 & Rayleigh, 0.1 & Log Normal, 0.04 \\
\hline 1962 Conservative & Weibull, 0.49 & Rayleigh, 0.17 & Log Normal, 0.17 \\
\hline 1963 Liberal & Log Normal, 0.58 & Weibull, 0.09 & Rayleigh, 0.01 \\
\hline 1963 Conservative & Log Normal, 0.52 & Rayleigh, 0.43 & Weibull, 0.32 \\
\hline 1964 Labour & Weibull, 0.75 & Folded Normal, 0.18 & Log Normal, 0.08 \\
\hline 1965 Labour & Log Normal, 0.1 & Weibull, 0.09 & General Pareto, 0.02 \\
\hline 1965 Conservative & Log Normal, 0.49 & Weibull, 0.25 & Normal, 0.00 \\
\hline 1966 Labour & Weibull, 0.46 & Folded Normal, 0.06 & Log Normal, 0.02 \\
\hline 1966 Conservative & Weibull, 0.32 & Log Normal, 0.19 & Folded Normal, 0.02 \\
\hline 1967 Labour & Weibull, 0.66 & Folded Normal, 0.04 & Log Normal, 0.01 \\
\hline 1967 Conservative & Log Normal, 0.36 & Weibull, 0.13 & Half Normal, 0.00 \\
\hline 1968 Labour & Weibull, 0.73 & Folded Normal, 0.07 & Log Normal, 0.01 \\
\hline 1968 Conservative & Log Normal, 0.22 & Weibull, 0.16 & Rayleigh, 0.00 \\
\hline 1969 Labour & Weibull, 0.55 & Folded Normal, 0.03 & Normal, 0.00 \\
\hline 1969 Conservative & Weibull, 0.18 & Log Normal, 0.05 & Half Normal, 0.00 \\
\hline 1970 Labour & Weibull, 0.28 & Log Normal, 0.03 & Folded Normal, 0.01 \\
\hline 1970 Conservative & Log Normal, 0.41 & Weibull, 0.35 & Rayleigh, 0.16 \\
\hline 1971 Conservative & Log Normal, 0.21 & Weibull, 0.15 & Rayleigh, 0.1 \\
\hline 1971 Labour & Weibull, 0.43 & Folded Normal, 0.05 & Normal, 0.01 \\
\hline 1972 Conservative & Log Normal, 0.37 & Weibull, 0.21 & Folded Normal, 0.07 \\
\hline 1972 Labour & Weibull, 0.66 & Log Normal, 0.06 & Normal, 0.00 \\
\hline 1973 Conservative & Log Normal, 0.17 & Weibull, 0.01 & Folded Normal, 0.00 \\
\hline 1973 Labour & Weibull, 0.57 & Folded Normal, 0.1 & Normal, 0.04 \\
\hline 1974 Labour & Weibull, 0.81 & Log Normal, 0.02 & Normal, 0.01 \\
\hline 1975 Conservative & Log Normal, 0.53 & Weibull, 0.28 & Rayleigh, 0.06 \\
\hline 1975 Labour & Weibull, 0.41 & Folded Normal, 0.04 & Log Normal, 0.02 \\
\hline 1976 Conservative & Weibull, 0.23 & Log Normal, 0.07 & Normal, 0.00 \\
\hline 1976 Labour & Weibull, 0.24 & Log Normal, 0.05 & Normal, 0.00 \\
\hline 1977 Conservative & Weibull, 0.48 & Normal, 0.03 & Rayleigh, 0.03 \\
\hline 1997 Labour & Weibull, 0.54 & Log Normal, 0.03 & Folded Normal, 0.01 \\
\hline 1977 Liberal a & Weibull, 0.66 & Log Normal, 0.10 & Rayleigh, 0.02 \\
\hline 19771 Liberal b & Log Normal, 0.67 & Weibull, 0.3 & Folded Normal, 0.01 \\
\hline 1978 Conservative & Weibull, 0.26 & Log Normal, 0.04 & Folded Normal, 0.01 \\
\hline 1978 Labour & Weibull, 0.19 & Log Normal, 0.01 & Normal, 0.00 \\
\hline 1978 Liberal & Weibull, 0.28 & Log Normal, 0.12 & Folded Normal, 0.05 \\
\hline 1979 Conservative & Log Normal, 0.30 & Weibull, 0.12 & Folded Normal, 0.00 \\
\hline 1979 Labour & Weibull, 0.17 & Log Normal, 0.02 & Folded Normal, 0.00 \\
\hline 1989 Liberal & Weibull, 0.58 & Rayleigh, 0.03 & Normal, 0.02 \\
\hline 1980 Conservative & Weibull, 0.45 & Rayleigh, 0.37 & Log Normal, 0.17 \\
\hline 1980 Labour & Log Normal, 0.14 & Weibull, 0.02 & Folded Normal, 0.00 \\
\hline 1980 Liberal & Weibull, 0.63 & Log Normal, 0.11 & Rayleigh, 0.02 \\
\hline 1981 Conservative & Weibull, 0.69 & Rayleigh, 0.08 & Log Normal, 0.08 \\
\hline 1981 Labour & Log Normal, 0.51 & Weibull, 0.20 & Half Normal, 0.00 \\
\hline 1981 Liberal & Weibull, 0.31 & Log Normal, 0.19 & Folded Normal, 0.02 \\
\hline $\begin{array}{c}1982 \text { SDP-Liberal } \\
\text { Alliance b }\end{array}$ & Weibull, 0.69 & Folded Normal, 0.34 & Rayleigh, 0.34 \\
\hline 1982 Conservative & Weibull, 0.18 & Rayleigh, 0.05 & Log Normal, 0.05 \\
\hline 1982 Labour & Weibull, 0.96 & Rayleigh, 0.26 & Normal, 0.15 \\
\hline 1982 Liberal & Weibull, 0.24 & Log Normal, 0.05 & Rayleigh, 0.01 \\
\hline 1983 Conservative & Weibull, 0.17 & Log Normal, 0.13 & Rayleigh, 0.06 \\
\hline 1983 Labour & Weibull, 0.57 & Folded Normal, 0.1 & Rayleigh, 0.08 \\
\hline
\end{tabular}




\begin{tabular}{|c|c|c|c|}
\hline Year, Party & I Place, $p$-Value & II Place, $p$-Value & III Place, $p$-Value \\
\hline 1983 Liberal & Weibull, 0.51 & Rayleigh, 0.41 & Folded Normal, 0.05 \\
\hline 1984 Conservative & Weibull, 0.81 & Folded Normal, 0.21 & Normal, 0.02 \\
\hline 1984 Labour & Weibull, 0.60 & Normal, 0.05 & Folded Normal, 0.04 \\
\hline 1984 Liberal & Weibull, 0.07 & Rayleigh, 0.02 & Log Normal, 0.00 \\
\hline 1985 Conservative & Weibull, 0.23 & Log Normal, 0.10 & Rayleigh, 0.05 \\
\hline 1985 Labour & Log Normal, 0.42 & Weibull, 0.29 & Half Normal, 0.08 \\
\hline 1985 Liberal & Weibull, 0.63 & Log Normal, 0.08 & Rayleigh, 0.05 \\
\hline 1986 Conservative & Weibull, 0.35 & Log Normal, 0.09 & Folded Normal, 0.07 \\
\hline 1986 Labour & Weibull, 0.64 & Log Normal, 0.04 & Normal, 0.01 \\
\hline 1986 Liberal & Weibull, 0.28 & Log Normal, 0.01 & Folded Normal, 0.01 \\
\hline 1987 Conservative & Weibull, 0.51 & Rayleigh, 0.09 & Log Normal, 0.02 \\
\hline 1987 Labour & Weibull, 0.21 & Log Normal, 0.06 & Folded Normal, 0.01 \\
\hline $\begin{array}{l}1987 \text { SDP-Liberal } \\
\text { Alliance a }\end{array}$ & Weibull, 0.61 & Log Normal, 0.25 & Folded Normal, 0.15 \\
\hline $\begin{array}{c}1987 \text { SDP-Liberal } \\
\text { Alliance b }\end{array}$ & Log Normal, 0.37 & Weibull, 0.16 & Rayleigh, 0.03 \\
\hline 1988 Conservative & Weibull, 0.47 & Rayleigh, 0.09 & Folded Normal, 0.03 \\
\hline 1988 Labour & Log Normal, 0.22 & Weibull, 0.03 & Half Normal, 0.00 \\
\hline 1988 Liberal & Log Normal, 0.9 & Weibull, 0.42 & Rayleigh, 0.07 \\
\hline 1989 Conservative & Weibull, 0.12 & Rayleigh, 0.05 & Log Normal, 0.01 \\
\hline 1989 Labour & Log Normal, 0.09 & Weibull, 0.06 & Half Normal, 0.00 \\
\hline 1990 Conservative & Weibull, 0.16 & Log Normal, 0.02 & Folded Normal, 0.00 \\
\hline 1990 Labour & Log Normal, 0.24 & Weibull, 0.02 & Half Normal, 0.00 \\
\hline 1991 Conservative & Weibull, 0.11 & Log Normal, 0.01 & Rayleigh, 0.00 \\
\hline 1991 Labour & Weibull, 0.11 & Log Normal, 0.04 & Normal, 0.00 \\
\hline 1992 Conservative & Weibull, 0.26 & Folded Normal, 0.00 & Log Normal, 0.00 \\
\hline 1992 Labour & Weibull, 0.42 & Log Normal, 0.05 & Rayleigh, 0.00 \\
\hline $\begin{array}{l}1992 \text { Liberal } \\
\text { Democrat } 1\end{array}$ & Weibull, 0.39 & Log Normal, 0.18 & Normal, 0.00 \\
\hline 1993 Conservative & Weibull, 0.23 & Log Normal, 0.02 & Folded Normal, 0.00 \\
\hline 1993 Labour & Weibull, 0.51 & Rayleigh, 0.22 & Normal, 0.09 \\
\hline $\begin{array}{c}1993 \text { Liberal } \\
\text { Democrat }\end{array}$ & Folded Normal, 0.51 & Weibull, 0.43 & Normal, 0.10 \\
\hline 1994 Conservative & Weibull, 0.11 & Log Normal, 0.05 & Normal, 0.00 \\
\hline 1994 Labour & Weibull, 0.36 & Log Normal, 0.01 & Normal, 0.00 \\
\hline $\begin{array}{c}1994 \text { Liberal } \\
\text { Democrat }\end{array}$ & Weibull, 0.88 & Folded Normal, 0.17 & Rayleigh, 0.14 \\
\hline 1995 Conservative & Weibull, 0.17 & Rayleigh, 0.01 & Log Normal, 0.00 \\
\hline 1995 Labour & Log Normal, 0.25 & Weibull, 0.12 & Half Normal, 0.00 \\
\hline 1996 Conservative & Log Normal, 0.14 & Weibull, 0.03 & Folded Normal, 0.00 \\
\hline 1996 Labour & Log Normal, 0.26 & Weibull, 0.03 & Folded Normal, 0.00 \\
\hline $\begin{array}{c}1996 \text { Liberal } \\
\text { Democrat }\end{array}$ & Weibull, 0.44 & Log Normal, 0.003 & Normal, 0.00 \\
\hline 1997 Conservative & Weibull, 0.44 & Folded Normal, 0.33 & Log Normal, 0.31 \\
\hline 1997 Labour & Log Normal, 0.12 & Weibull, 0.001 & Half Normal, 0.00 \\
\hline 1998 Conservative & Weibull, 0.07 & Log Normal, 0.05 & Folded Normal, 0.00 \\
\hline 1998 Labour & Log Normal, 0.19 & Weibull, 0.13 & Folded Normal, 0.00 \\
\hline $\begin{array}{c}1988 \text { Liberal } \\
\text { Democrat }\end{array}$ & Weibull, 0.09 & Log Normal, 0.001 & Folded Normal, 0.00 \\
\hline 1999 Conservative & Log Normal, 0.07 & Weibull, 0.04 & Folded Normal, 0.00 \\
\hline 1999 Labour & Log Normal, 0.01 & Half Normal, 0.00 & Weibull, 0.00 \\
\hline $\begin{array}{l}1999 \text { Liberal } \\
\text { Democrat a }\end{array}$ & Weibull, 0.74 & Folded Normal, 0.28 & Log Normal, 0.15 \\
\hline $\begin{array}{l}1999 \text { Liberal } \\
\text { Democrat b }\end{array}$ & Log Normal, 0.04 & Weibull, 0.00 & Rayleigh, 0.00 \\
\hline 2000 Conservative & Weibull, 0.01 & Log Normal, 0.01 & Normal, 0.00 \\
\hline 2000 Labour & Log Normal, 0.02 & Weibull, 0.00 & Folded Normal, 0.00 \\
\hline
\end{tabular}




\begin{tabular}{|c|c|c|c|}
\hline Year, Party & I Place, $p$-Value & II Place, $p$-Value & III Place, $p$-Value \\
\hline $2000 \mathrm{~L}$ & Log Normal, 0.01 & Weibull, 0.00 & Half Normal, 0.00 \\
\hline 2001 Conservative & Log Normal, 0.17 & Weibull, 0.1 & Folded Normal, 0.02 \\
\hline 2001 Labour & Log Normal, 0.52 & Weibull, 0.00 & Half Normal, 0.00 \\
\hline $\begin{array}{c}2001 \text { Liberal } \\
\text { Democrat }\end{array}$ & Weibull, 0.13 & Log Normal, 0.06 & Half Normal, 0.00 \\
\hline 2002 Conservative & Weibull, 0.28 & Rayleigh, 0.27 & Log Normal, 0.14 \\
\hline 2002 Labour & Log Normal, 0.10 & Weibull, 0.00 & Folded Normal, 0.00 \\
\hline $\begin{array}{c}2002 \text { Liberal } \\
\text { Democrat }\end{array}$ & Weibull, 0.21 & Rayleigh, 0.05 & Folded Normal, 0.03 \\
\hline 2003 Conservative & Weibull, 0.16 & Rayleigh, 0.11 & Folded Normal, 0.01 \\
\hline 2003 Labour & Log Normal, 0.20 & Weibull, 0.02 & Half Normal, 0.00 \\
\hline $\begin{array}{c}2003 \text { Liberal } \\
\text { Democrat }\end{array}$ & Weibull, 0.05 & Rayleigh, 0.03 & Folded Normal, 0.00 \\
\hline 2004 Conservative & Weibull, 0.08 & Rayleigh, 0.07 & Folded Normal, 0.00 \\
\hline 2004 Labour & Weibull, 0.24 & Log Normal, 0.18 & Half Normal, 0.01 \\
\hline $\begin{array}{c}2004 \text { Liberal } \\
\text { Democrat } 1\end{array}$ & Weibull, 0.19 & Folded Normal, 0.01 & Log Normal, 0.00 \\
\hline 2005 Conservative & Weibull, 0.64 & Rayleigh, 0.30 & Log Normal, 0.14 \\
\hline 2005 Labour & Weibull, 0.07 & Log Normal, 0.05 & Folded Normal, 0.00 \\
\hline $\begin{array}{c}2005 \text { Liberal } \\
\text { Democrat }\end{array}$ & Rayleigh, 0.20 & Weibull, 0.19 & Log Normal, 0.11 \\
\hline 2006 Conservative a & Weibull, 0.15 & Log Normal, 0.05 & Folded Normal, 0.00 \\
\hline 2006 Conservative $\mathrm{b}$ & Weibull, 0.01 & Log Normal, 0.00 & Rayleigh, 0.00 \\
\hline 2006 Labour & Log Normal, 0.12 & Weibull, 0.03 & Folded Normal, 0.00 \\
\hline $\begin{array}{c}2006 \text { Liberal } \\
\text { Democrat }\end{array}$ & Log Normal, 0.24 & Weibull, 0.03 & Rayleigh, 0.01 \\
\hline 2007 Conservative & Weibull, 0.10 & Log Normal, 0.09 & Folded Normal, 0.00 \\
\hline 2007 Labour & Weibull, 0.16 & Rayleigh, 0.02 & Log Normal, 0.02 \\
\hline $\begin{array}{c}2007 \text { Liberal } \\
\text { Democrat }\end{array}$ & Rayleigh, 0.19 & Weibull, 0.11 & Log Normal, 0.05 \\
\hline 2008 Conservative & Weibull, 0.17 & Log Normal, 0.03 & Normal, 0.00 \\
\hline 2008 Labour & Weibull, 0.19 & Log Normal, 0.06 & Rayleigh, 0.01 \\
\hline $\begin{array}{c}2008 \text { Liberal } \\
\text { Democrat } 1\end{array}$ & Weibull, 0.49 & Rayleigh, 0.07 & Normal, 0.01 \\
\hline 2009 Conservative & Weibull, 0.06 & Log Normal, 0.01 & Rayleigh, 0.00 \\
\hline 2009 Labour & Rayleigh, 0.68 & Weibull, 0.53 & Folded Normal, 0.1 \\
\hline $\begin{array}{c}2009 \text { Liberal } \\
\text { Democrat }\end{array}$ & Weibull, 0.17 & Rayleigh, 0.05 & Folded Normal, 0.01 \\
\hline 2010 Conservative & Weibull, 0.23 & Log Normal, 0.00 & Folded Normal, 0.00 \\
\hline 2010 Labour & Weibull, 0.45 & Folded Normal, 0.04 & Rayleigh, 0.02 \\
\hline $\begin{array}{c}2010 \text { Liberal } \\
\text { Democrat } 1\end{array}$ & Log Normal, 0.16 & Weibull, 0.03 & Rayleigh, 0.01 \\
\hline 2011 Conservative & Weibull, 0.30 & Rayleigh, 0.0003 & Log Normal, 0.00 \\
\hline 2011 Labour & Log Normal, 0.02 & Weibull, 0.01 & Normal, 0.00 \\
\hline $\begin{array}{c}2011 \text { Liberal } \\
\text { Democrat }\end{array}$ & Weibull, 0.25 & Folded Normal, 0.00 & Log Normal, 0.00 \\
\hline 2012 Conservative & Weibull, 0.16 & Folded Normal, 0.02 & Half Normal, 0.01 \\
\hline 2012 Labour & Weibull, 0.01 & Log Normal, 0.01 & Folded Normal, 0.00 \\
\hline $\begin{array}{c}2012 \text { Liberal } \\
\text { Democrat }\end{array}$ & Weibull, 0.49 & Log Normal, 0.13 & Rayleigh, 0.03 \\
\hline 2013 Conservative & Weibull, 0.19 & Log Normal, 0.03 & Folded Normal, 0.00 \\
\hline
\end{tabular}




\begin{tabular}{|c|c|c|c|}
\hline Year, Party & I Place, $p$-Value & II Place, $p$-Value & III Place, $p$-Value \\
\hline 2013 Labour & Log Normal, 0.11 & Weibull, 0.02 & Normal, 0.00 \\
\hline $\begin{array}{l}2013 \text { Liberal } \\
\text { Democrat }\end{array}$ & Weibull, 0.64 & Rayleigh, 0.11 & Normal, 0.03 \\
\hline 2014 Conservative & Weibull, 0.13 & Log Normal, 0 & Folded Normal, 0.00 \\
\hline 2014 Labour & Weibull, 0.17 & Folded Normal, 0.01 & Rayleigh, 0.00 \\
\hline $\begin{array}{l}2014 \text { Liberal } \\
\text { Democrat }\end{array}$ & Weibull, 0.32 & Folded Normal, 0.13 & Normal, 0.03 \\
\hline 2015 Conservative & Weibull, 0.2 & Folded Normal, 0.001 & Log Normal, 0.00 \\
\hline 2015 Labour & Weibull, 0.18 & Log Normal, 0.01 & Rayleigh, 0.00 \\
\hline $\begin{array}{l}2015 \text { Liberal } \\
\text { Democrat }\end{array}$ & Weibull, 0.42 & Folded Normal, 0.07 & Rayleigh, 0.03 \\
\hline 2016 Conservative & Log Normal, 0.23 & Weibull, 0.01 & Normal, 0.00 \\
\hline 2016 Labour & Weibull, 0.37 & Rayleigh, 0.31 & Log Normal, 0.12 \\
\hline $\begin{array}{l}2016 \text { Liberal } \\
\text { Democrat }\end{array}$ & Log Normal, 0.14 & Weibull, 0.07 & Normal, 0.00 \\
\hline 2017 Conservative & Log Normal, 0.05 & Weibull, 0.02 & Normal, 0.00 \\
\hline 2017 Labour & Weibull, 0.16 & Log Normal, 0.1 & Folded Normal, 0.01 \\
\hline $\begin{array}{l}2017 \text { Liberal } \\
\text { Democrat }\end{array}$ & Weibull, 0.31 & Rayleigh, 0.11 & Folded Normal, 0.04 \\
\hline 2018 Conservative & Log Normal, 0.12 & Rayleigh, 0.01 & Weibull, 0.003 \\
\hline 2018 Labour & Rayleigh, 0.18 & Weibull, 0.16 & Log Normal, 0.09 \\
\hline $\begin{array}{c}2018 \text { Liberal } \\
\text { Democrat }\end{array}$ & Weibull, 0.41 & Rayleigh, 0.1 & Log Normal, 0.09 \\
\hline
\end{tabular}

\section{Appendix B}

The shape and scale parameters for the Weibull distributions used for the description of the empirical sentence length distributions

DATA FOR USA

\begin{tabular}{cccc}
\hline Year & $p$-Value & $\lambda$, Scale & $k$, Shape \\
\hline 1817 & 0.80 & 28.4 & 1.8 \\
1821 & 0.41 & 37.9 & 1.9 \\
1825 & 0.79 & 36.9 & 1.9 \\
1841 & 0.38 & 43.9 & 1.9 \\
1845 & 0.30 & 35.4 & 1.8 \\
1857 & 0.96 & 35.8 & 2.3 \\
1861 & 0.91 & 29.3 & 1.7 \\
1873 & 0.85 & 31.3 & 2.0 \\
1885 & 0.80 & 43.0 & 2.2 \\
1889 & 0.54 & 31.6 & 2.0 \\
1897 & 0.57 & 34.4 & 2.0 \\
1909 & 0.97 & 38.3 & 1.9 \\
1913 & 0.18 & 25.0 & 1.4 \\
1917 & 0.30 & 25.3 & 1.5 \\
1921 & 0.43 & 25.3 & 1.7 \\
1925 & 0.20 & 23.0 & 2.0 \\
1929 & 0.26 & 22.2 & 1.9 \\
1941 & 0.73 & 21.7 & 1.6 \\
1949 & 0.54 & 22.0 & 2.4 \\
1957 & 0.24 & 20.1 & 2.0 \\
1977 & 0.90 & 22.6 & 2.3 \\
\hline
\end{tabular}




\begin{tabular}{cccc}
\hline Year, Party & I Place, $\boldsymbol{p}$-Value & II Place, $\boldsymbol{p}$-Value & III Place, $\boldsymbol{p}$-Value \\
\hline 1985 & 0.22 & 22.1 & 1.9 \\
1989 & 0.49 & 18.5 & 2.0 \\
1993 & 0.89 & 18.5 & 2.3 \\
1997 & 0.18 & 20.7 & 2.0 \\
2001 & 0.45 & 18.0 & 2.5 \\
2005 & 0.92 & 23.7 & 2.3 \\
2009 & 0.97 & 23.3 & 1.5 \\
2013 & 0.63 & 27.8 & 2.3 \\
2017 & 0.71 & 16.7 & 1.7 \\
2021 & 0.67 & 17.2 & 1.6 \\
\hline
\end{tabular}

DATA FOR UK

\begin{tabular}{|c|c|c|c|}
\hline Year, Party & $p$-Value & $\lambda$, Scale & $k$, Shape \\
\hline 1895 Liberal & 0.37 & 33.7 & 1.6 \\
\hline 1896 Liberal & 0.28 & 28.3 & 1.6 \\
\hline 1897 Conservative & 0.47 & 32.6 & 1.5 \\
\hline 1899 Liberal & 0.29 & 32.9 & 1.6 \\
\hline 1900 Conservative & 0.87 & 38.2 & 1.7 \\
\hline 1901 Liberal & 0.31 & 25.3 & 1.4 \\
\hline 1902 Conservative & 0.30 & 35.0 & 1.3 \\
\hline 1903 Conservative & 0.84 & 36.4 & 1.3 \\
\hline 1903 Liberal & 0.51 & 29.5 & 1.5 \\
\hline 1904 Conservative & 0.64 & 40.2 & 1.5 \\
\hline 1905 Liberal & 0.18 & 29.3 & 1.5 \\
\hline 1906 Conservative & 0.36 & 36.2 & 1.4 \\
\hline 1907 Conservative & 0.16 & 34.6 & 1.2 \\
\hline 1907 Liberal & 0.53 & 35.9 & 1.5 \\
\hline 1908 Liberal & 0.59 & 32.5 & 1.4 \\
\hline 1908 Conservative & 0.66 & 38.0 & 1.3 \\
\hline 1909 Liberal & 0.69 & 38.7 & 1.6 \\
\hline 1909 Conservative & 0.34 & 32.4 & 1.4 \\
\hline 1910 Liberal & 0.38 & 31.5 & 1.4 \\
\hline 1910 Conservative & 0.92 & 31.1 & 1.4 \\
\hline 1911 Conservative & 0.72 & 26.9 & 1.5 \\
\hline 1912 Liberal & 0.55 & 36.0 & 1.4 \\
\hline 1912 Conservative & 0.17 & 25.4 & 1.4 \\
\hline 1913 Conservative & 0.07 & 27.0 & 1.4 \\
\hline 1913 Liberal & 0.91 & 38.7 & 1.5 \\
\hline 1918 Liberal & 0.82 & 33.6 & 1.8 \\
\hline 1919 Liberal & 0.98 & 33.2 & 1.5 \\
\hline 1920 Liberal & 0.66 & 30.0 & 1.4 \\
\hline 1921 Liberal & 0.67 & 27.1 & 1.4 \\
\hline 1921 Conservative & 0.09 & 24.2 & 1.3 \\
\hline 1922 Liberal & 0.90 & 28.4 & 1.4 \\
\hline 1922 Conservative & 0.52 & 28.3 & 1.5 \\
\hline 1923 Liberal & 0.85 & 33.4 & 1.6 \\
\hline 1924 Liberal & 0.50 & 32.4 & 1.9 \\
\hline 1924 Labour & 0.77 & 28.4 & 1.4 \\
\hline 1924 Conservative & 0.75 & 33.8 & 1.6 \\
\hline 1925 Liberal & 0.60 & 30.4 & 1.9 \\
\hline 1925 Conservative & 0.47 & 32.0 & 1.6 \\
\hline 1926 Conservative & 0.21 & 33.7 & 1.7 \\
\hline
\end{tabular}




\begin{tabular}{|c|c|c|c|}
\hline Year, Party & I Place, $p$-Value & II Place, $p$-Value & III Place, $p$-Value \\
\hline 1927 Liberal & 0.21 & 23.3 & 1.6 \\
\hline 1927 Conservative & 0.19 & 25.9 & 1.6 \\
\hline 1929 Liberal & 0.19 & 20.3 & 1.7 \\
\hline 1929 Conservative & 0.61 & 26.9 & 1.5 \\
\hline 1930 Liberal & 0.16 & 22.0 & 1.7 \\
\hline 1932 Conservative & 0.78 & 25.2 & 1.8 \\
\hline 1932 Liberal & 0.45 & 29.7 & 1.6 \\
\hline 1933 Conservative & 0.57 & 30.3 & 1.7 \\
\hline 1934 Conservative & 0.75 & 30.1 & 1.8 \\
\hline 1935 Conservative & 0.61 & 34.2 & 1.8 \\
\hline 1936 Liberal & 0.19 & 35.2 & 1.4 \\
\hline 1937 Liberal & 0.74 & 38.6 & 2.4 \\
\hline 1941 Liberal & 0.68 & 30.8 & 1.8 \\
\hline 1942 Liberal & 0.67 & 27.0 & 1.8 \\
\hline 1943 Liberal & 0.51 & 36.0 & 1.7 \\
\hline 1945 Liberal & 0.62 & 27.1 & 1.7 \\
\hline 1946 Labour & 0.08 & 21.3 & 1.7 \\
\hline 1947 Labour & 0.21 & 19.6 & 1.6 \\
\hline 1948 Labour & 0.51 & 24.4 & 1.7 \\
\hline 1949 Labour & 0.47 & 23.5 & 1.8 \\
\hline 1950 Labour & 0.39 & 23.0 & 1.8 \\
\hline 1951 Labour & 0.19 & 21.3 & 1.8 \\
\hline 1955 Conservative & 0.32 & 23.7 & 1.7 \\
\hline 1956 Conservative & 0.11 & 19.7 & 1.8 \\
\hline 1958 Conservative & 0.13 & 21.7 & 1.9 \\
\hline 1960 Conservative & 0.53 & 20.1 & 2 \\
\hline 1961 Conservative & 0.68 & 21.1 & 1.8 \\
\hline 1962 Conservative & 0.49 & 23.1 & 1.9 \\
\hline 1963 Liberal & 0.09 & 22.6 & 1.8 \\
\hline 1963 Conservative & 0.32 & 27.5 & 2.0 \\
\hline 1964 Labour & 0.75 & 34.6 & 1.7 \\
\hline 1965 Labour & 0.09 & 29.6 & 1.3 \\
\hline 1965 Conservative & 0.25 & 19.9 & 1.6 \\
\hline 1966 Labour & 0.46 & 30.9 & 1.6 \\
\hline 1966 Conservative & 0.32 & 25.8 & 1.6 \\
\hline 1967 Labour & 0.66 & 27.0 & 1.5 \\
\hline 1967 Conservative & 0.13 & 24.0 & 1.5 \\
\hline 1968 Labour & 0.73 & 22.4 & 1.6 \\
\hline 1968 Conservative & 0.16 & 20.3 & 1.7 \\
\hline 1969 Labour & 0.55 & 17.8 & 1.7 \\
\hline 1969 Conservative & 0.18 & 21.3 & 1.5 \\
\hline 1970 Labour & 0.28 & 25.0 & 1.5 \\
\hline 1970 Conservative & 0.35 & 25.6 & 1.9 \\
\hline 1971 Conservative & 0.15 & 24.1 & 2.0 \\
\hline 1971 Labour & 0.43 & 26.1 & 1.6 \\
\hline 1972 Conservative & 0.21 & 24.1 & 1.9 \\
\hline 1972 Labour & 0.66 & 24.3 & 1.6 \\
\hline 1973 Labour & 0.57 & 25.3 & 1.6 \\
\hline 1974 Labour & 0.81 & 29.1 & 1.7 \\
\hline 1975 Conservative & 0.28 & 24.6 & 1.8 \\
\hline 1975 Labour & 0.41 & 26.2 & 1.5 \\
\hline 1976 Conservative & 0.23 & 16.6 & 1.6 \\
\hline 1976 Labour & 0.24 & 22.8 & 1.7 \\
\hline 1977 Conservative & 0.48 & 19.5 & 1.7 \\
\hline 1997 Labour & 0.54 & 24.4 & 1.6 \\
\hline 1977 Liberal a & 0.66 & 26.3 & 1.7 \\
\hline 19771 Liberal b & 0.3 & 26.1 & 1.7 \\
\hline
\end{tabular}




\begin{tabular}{|c|c|c|c|}
\hline Year, Party & I Place, $p$-Value & II Place, $p$-Value & III Place, $p$-Value \\
\hline 1978 Conservative & 0.26 & 18.4 & 1.7 \\
\hline 1978 Labour & 0.19 & 21.8 & 1.6 \\
\hline 1978 Liberal & 0.28 & 22.4 & 1.8 \\
\hline 1979 Conservative & 0.12 & 17.6 & 1.7 \\
\hline 1979 Labour & 0.17 & 27.1 & 1.5 \\
\hline 1989 Liberal & 0.58 & 21.2 & 1.8 \\
\hline 1980 Conservative & 0.45 & 20.2 & 2.0 \\
\hline 1980 Liberal & 0.63 & 23.8 & 1.7 \\
\hline 1981 Conservative & 0.69 & 21.6 & 1.8 \\
\hline 1981 Labour & 0.2 & 26.7 & 1.7 \\
\hline 1981 Liberal & 0.31 & 23.5 & 1.8 \\
\hline $\begin{array}{l}1982 \text { SDP-Liberal } \\
\text { Alliance b }\end{array}$ & 0.69 & 25.9 & 1.9 \\
\hline 1982 Conservative & 0.18 & 17.6 & 1.9 \\
\hline 1982 Labour & 0.96 & 31.3 & 1.8 \\
\hline 1982 Liberal & 0.24 & 20.4 & 1.7 \\
\hline 1983 Conservative & 0.17 & 19.1 & 1.8 \\
\hline 1983 Labour & 0.57 & 29.5 & 1.8 \\
\hline 1983 Liberal & 0.51 & 22.4 & 2.0 \\
\hline 1984 Conservative & 0.81 & 19.5 & 1.7 \\
\hline 1984 Labour & 0.6 & 23.8 & 1.6 \\
\hline 1984 Liberal & 0.07 & 21.2 & 1.8 \\
\hline 1985 Conservative & 0.23 & 16.7 & 1.8 \\
\hline 1985 Labour & 0.29 & 27.7 & 1.4 \\
\hline 1985 Liberal & 0.63 & 20.1 & 1.8 \\
\hline 1986 Conservative & 0.35 & 18.3 & 1.8 \\
\hline 1986 Labour & 0.64 & 27.9 & 1.6 \\
\hline 1986 Liberal & 0.28 & 21.2 & 1.7 \\
\hline 1987 Conservative & 0.51 & 17.1 & 1.9 \\
\hline 1987 Labour & 0.21 & 25.5 & 1.6 \\
\hline $\begin{array}{c}1987 \text { SDP-Liberal } \\
\text { Alliance a }\end{array}$ & 0.61 & 18.2 & 1.7 \\
\hline $\begin{array}{l}1987 \text { SDP-Liberal } \\
\text { Alliance b }\end{array}$ & 0.16 & 20.5 & 1.9 \\
\hline 1988 Conservative & 0.47 & 16.5 & 1.9 \\
\hline 1988 Liberal & 0.42 & 20.6 & 1.8 \\
\hline 1989 Conservative & 0.12 & 16.9 & 1.9 \\
\hline 1989 Labour & 0.06 & 22.0 & 1.5 \\
\hline 1990 Conservative & 0.16 & 15.1 & 1.7 \\
\hline 1991 Conservative & 0.11 & 13.0 & 1.8 \\
\hline 1991 Labour & 0.11 & 22.7 & 1.6 \\
\hline 1992 Conservative & 0.26 & 12.8 & 1.7 \\
\hline 1992 Labour & 0.42 & 23.8 & 1.7 \\
\hline $\begin{array}{c}1992 \text { Liberal } \\
\text { Democrat }\end{array}$ & 0.39 & 18.8 & 1.6 \\
\hline 1993 Conservative & 0.23 & 17.5 & 1.6 \\
\hline 1993 Labour & 0.51 & 25.6 & 1.8 \\
\hline $\begin{array}{c}1993 \text { Liberal } \\
\text { Democrat }\end{array}$ & 0.43 & 19.9 & 1.7 \\
\hline 1994 Conservative & 0.11 & 19.6 & 1.6 \\
\hline 1994 Labour & 0.36 & 19.6 & 1.6 \\
\hline $\begin{array}{c}1994 \text { Liberal } \\
\text { Democrat }\end{array}$ & 0.88 & 17.8 & 1.8 \\
\hline 1995 Conservative & 0.17 & 12.7 & 1.8 \\
\hline 1995 Labour & 0.12 & 21.7 & 1.5 \\
\hline $\begin{array}{c}1996 \text { Liberal } \\
\text { Democrat }\end{array}$ & 0.44 & 15.3 & 1.6 \\
\hline 1997 Conservative & 0.44 & 17.1 & 1.6 \\
\hline
\end{tabular}




\begin{tabular}{|c|c|c|c|}
\hline Year, Party & I Place, $p$-Value & II Place, $p$-Value & III Place, $p$-Value \\
\hline 1998 Conservative & 0.07 & 18.1 & 1.7 \\
\hline 1998 Labour & 0.13 & 20.9 & 1.6 \\
\hline $\begin{array}{l}1988 \text { Liberal } \\
\text { Democrat }\end{array}$ & 0.09 & 13.1 & 1.5 \\
\hline $\begin{array}{l}1999 \text { Liberal } \\
\text { Democrat a }\end{array}$ & 0.74 & 15.9 & 1.7 \\
\hline 2001 Conservative & 0.1 & 18.0 & 2.4 \\
\hline $\begin{array}{c}2001 \text { Liberal } \\
\text { Democrat }\end{array}$ & 0.13 & 13.4 & 1.5 \\
\hline 2002 Conservative & 0.28 & 16.8 & 2.0 \\
\hline $\begin{array}{c}2002 \text { Liberal } \\
\text { Democrat }\end{array}$ & 0.21 & 13.4 & 1.9 \\
\hline 2003 Conservative & 0.16 & 11.4 & 1.9 \\
\hline $\begin{array}{c}2003 \text { Liberal } \\
\text { Democrat }\end{array}$ & 0.05 & 12.4 & 1.9 \\
\hline 2004 Conservative & 0.08 & 12.0 & 2.0 \\
\hline 2004 Labour & 0.24 & 17.7 & 1.2 \\
\hline $\begin{array}{l}2004 \text { Liberal } \\
\text { Democrat }\end{array}$ & 0.19 & 14.8 & 1.6 \\
\hline 2005 Conservative & 0.64 & 16.7 & 1.9 \\
\hline 2005 Labour & 0.07 & 16.4 & 1.6 \\
\hline $\begin{array}{c}2005 \text { Liberal } \\
\text { Democrat }\end{array}$ & 0.19 & 15.3 & 2.0 \\
\hline 2006 Conservative a & 0.15 & 13.0 & 1.6 \\
\hline 2007 Conservative & 0.1 & 23.2 & 1.7 \\
\hline 2007 Labour & 0.16 & 23.8 & 1.9 \\
\hline $\begin{array}{c}2007 \text { Liberal } \\
\text { Democrat }\end{array}$ & 0.11 & 14.7 & 2.0 \\
\hline 2008 Conservative & 0.17 & 16.2 & 1.6 \\
\hline 2008 Labour & 0.19 & 25.6 & 1.8 \\
\hline $\begin{array}{l}2008 \text { Liberal } \\
\text { Democrat }\end{array}$ & 0.49 & 12.3 & 1.9 \\
\hline 2009 Conservative & 0.06 & 15.1 & 1.8 \\
\hline 2009 Labour & 0.53 & 23.8 & 2.0 \\
\hline $\begin{array}{c}2009 \text { Liberal } \\
\text { Democrat }\end{array}$ & 0.17 & 13.4 & 1.9 \\
\hline 2010 Conservative & 0.23 & 14.5 & 1.6 \\
\hline 2010 Labour & 0.45 & 18.3 & 1.8 \\
\hline 2011 Conservative & 0.3 & 14.5 & 1.7 \\
\hline $\begin{array}{c}2011 \text { Liberal } \\
\text { Democrat }\end{array}$ & 0.25 & 11.9 & 1.6 \\
\hline 2012 Conservative & 0.16 & 15.2 & 1.4 \\
\hline $\begin{array}{l}2012 \text { Liberal } \\
\text { Democrat }\end{array}$ & 0.49 & 19.4 & 1.8 \\
\hline 2013 Conservative & 0.19 & 14.4 & 1.6 \\
\hline $\begin{array}{l}2013 \text { Liberal } \\
\text { Democrat }\end{array}$ & 0.64 & 20.8 & 1.8 \\
\hline 2014 Conservative & 0.13 & 16.7 & 1.6 \\
\hline 2014 Labour & 0.17 & 14.9 & 1.8 \\
\hline $\begin{array}{c}2014 \text { Liberal } \\
\text { Democrat }\end{array}$ & 0.32 & 20.5 & 1.7 \\
\hline 2015 Conservative & 0.2 & 15.5 & 1.6 \\
\hline 2015 Labour & 0.18 & 15.7 & 1.7 \\
\hline $\begin{array}{l}2015 \text { Liberal } \\
\text { Democrat }\end{array}$ & 0.42 & 18.1 & 1.8 \\
\hline 2016 Labour & 0.37 & 23.6 & 2.0 \\
\hline
\end{tabular}




\begin{tabular}{cccc}
\hline Year, Party & I Place, $\boldsymbol{p}$-Value & II Place, $\boldsymbol{p}$-Value & III Place, $\boldsymbol{p}$-Value \\
\hline 2016 Liberal & 0.07 & 16.8 & 1.5 \\
Democrat & 0.16 & 19.7 & 1.8 \\
2017 Labour & 0.31 & 17.2 & 1.8 \\
2017 Liberal & 0.16 & 21.5 & 2.0 \\
Democrat & 0.41 & 18.7 & 1.8 \\
2018 Labour & & & \\
2018 Liberal & &
\end{tabular}

\section{References}

1. Köhler, R.; Altmann, G. Aims and methods of quantitative linguistics. In Problems of Quantitative Linguistic; RAM-Verlag: Ludenscheid, Germany, 2005; pp. 12-42.

2. Köhler, R. Synergetic linguistics. In Contributions to quantitative linguistics; Köhler, R., Rieger, B.B., Eds.; Springer: Berlin, Germany, 1991; pp. 41-51.

3. Best, K.H.; Rottmann, O. Quantitative Linguistics, an Invitation; RAM-Verlag: Ludenscheid, Germany, 2017.

4. Hernández-Fernández, A.; Torre, I.G.; Garrido, J.-M.; Lacasa, L. Linguistic Laws in Speech: The Case of Catalan and Spanish. Entropy 2019, 21, 1153. [CrossRef]

5. Corral, Á.; Serra, I. The brevity law as a scaling law, and a possible origin of zipf's law for word frequencies. Entropy 2020, $22,224$. [CrossRef] [PubMed]

6. Torre, I.G.; Luque, B.; Lacasa, L.; Kello, C.T.; Hernández-Fernández, A. On the physical origin of linguistic laws and lognormality in speech. R. Soc. Open Sci. 2019, 6, 191023. [CrossRef]

7. Liu, H.T.; Xu, C.S.; Liang, J. Dependency distance: A new perspective on syntactic patterns innatural languages. Phys. Life Reviews 2017, 21, 171-193. [CrossRef] [PubMed]

8. Udny Yule, G. In sentence- length as a statistical characteristic of style in prose: With application to two cases of disputed authorship. Biometrika 1939, 30, 363-390.

9. Lesskis, G.A. O zavisimosti mezhdu razmerom predlozheniya i kharakterom teksta. J. Vopr. Jazykoznaniya. 1963, 3, 92-112. (In Russian)

10. Admoni, V.G. Razmer predlozheniya i slovosochetaniya kak yavleniye sintaksicheskogo stroya. J. Vopr. Jazykoznaniya. 1966, 4, 111-118. (In Russian)

11. Burdayeva, T.V. Variantnost' Slozhnopodchinennogo Predlozheniya i Ekvivalentnykh yemu Struktur. Ph.D. Thesis, Samara State Pedagogical University, Samara, Russia, 26 June 2002. (In Russian).

12. Kamshilova, O.N.; Kapotova, N.S.; Razumova, V.V. Issledovaniye dliny i struktury predlozheniya v spetsial'nom korpuse tekstov. Korpusnaya Lingvistika; St. Petersburg University Publ: Saint Petersburg, Russia, 2008; pp. 183-187. (In Russian)

13. Kučera, H. Computational analysis of predicational structures in English. In Proceedings of the Coling: The 8th International Conference on Computational Linguistics, Tokyo, Japan, 30 September-4 October 1980; Volume 1, pp. 32-38.

14. Kornai, A. How many words are there? Glottometrics 2002, 4, 61-86.

15. Rudnicka, K. Variation of Sentence Length Across Time and Genre: Influence on the Syntactic Usage in English. Stud. Corpus Linguist. 2018, 85, 219-240.

16. Grigoryeva, Y.U.M. Dlina predlozheniya kak pokazatel' sintaksicheskikh izmeneniy v yazyke (na materiale perevodov Biblii na shvedskiy yazyk 1917 i 2000 gg.). Skandinavskaya Filologiya 2012, 12, 16-24. (In Russian)

17. Drutman, L. Is Congress Getting Dumber, or Just More Plainspoken? Available online: https://sunlightfoundation.com/2012/0 5/21/grade-level-congress/2012 (accessed on 25 July 2021).

18. Ostermeier, E. My Message is Simple: Obama's SOTU Written at 8th Grade Level for Third Straight Year. Available online: https:/ / smartpolitics.lib.umn.edu/2012/01/25/my-message-is-simple-obamas-so/2012 (accessed on 25 July 2021).

19. Sobkowicz, P.; Thelwall, M.; Buckley, K.; Georgios Paltoglou, G.; Sobkowicz, A. Lognormal distributions of user post lengths in Internet discussions-a consequence of the Weber-Fechner law? EPJ Data Sci. 2013, 2, 2. [CrossRef]

20. Ishida, M.; Ishida, K. On distributions of sentence lengths in Japanese writing. Glottometrics. 2007, 15, $28-44$.

21. Sigurd, B.; Eeg-Olofsson, M.; Van de Weijer, J. Word length, sentence length and frequency-Zipf revisited. Studia Linguistica 2004, 58, 37-52. [CrossRef]

22. Furuhashi, S.; Hayakawa, Y. Lognormality of the distribution of Japanese sentence lengths. J. Phys. Soc. Jpn. 2012, 81, 034004. [CrossRef]

23. Williams, C.B. A note on the statistical analysis of sentence-length as a criterion of literary style. Biometrika 1940, 31, 356-361. [CrossRef]

24. Wake, W.C. Sentence-length distributions of Greek authors. J. R. Stat. Soc. Ser. A 1957, 120, 331-346. [CrossRef]

25. Zipf, G.K. Human Behavior and the Principle of Least Effort: An Introduction to Human Ecology; Addison-Wesley Publishing: Cambridge, UK, 1949.

26. Mach, E. Popular Scientific Lectures; The Open Court Publishing Company: Chicago, IL, USA, 1894. 
27. Ferrer i Cancho, R.; Solé, R.V. Least effort and the origins of scaling in human language. Proc. Natl. Acad. Sci. USA 2003, 100, 788-791. [CrossRef]

28. Ferrer i Cancho, R. Non-crossing dependencies: Least effort, not grammar. In Towards a Theoretical Framework for Analyzing Complex Linguistic Networks; Mehler, A., Ed.; Springer: Berlin/Heidelberg, Germany, 2016; pp. 203-234.

29. Futrell, R.; Mahowald, K.; Gibson, E. Large-scale evidence of dependency length minimization in 37 languages. Proc. Natl. Acad. Sci. USA 2015, 112, 10336-10341. [CrossRef]

30. Gumbel, E. Statistics of Extremes; Columbia University Press: New York, NY, USA, 1962.

31. Leadbetter, M.R.; Rootzen, H.; Lindgren, G. Extremes and Related Properties of Random Sequences and Processes; Springer: New York, NY, USA, 1983.

32. Tucker, E.C.; Capps, C.J.; Shamir, L. A data science approach to 138 years of congressional speeches. Heliyon 2020, 6, e04417. [CrossRef] [PubMed]

33. Božić Lenard, D. Gender differences in the length of words and sentences on the corpus of congressional speeches. Imp. J. Interdiscip. Res. 2016, 2, 1417-1424.

34. Li, W.; Miramontes, P. Fitting ranked english and spanish letter frequency distribution in US and Mexican presidential speeches. J. Quant. Linguist. 2011, 18, 359-380. [CrossRef]

35. Inaugural Addresses of the Presidents of the United States. Available online: https://www.bartleby.com/124/ (accessed on 25 July 2021).

36. British Political Speech, Swansea University, UK. Available online: http://britishpoliticalspeech.org/index.htm (accessed on 25 July 2021).

37. Vieira, D.S.; Picoli, S.; Mendes, R.S. Robustness of sentence length measures in written texts. Phys. A Stat. Mech. Appl. 2018, 506, 749-754. [CrossRef]

38. Tsizhmovska, N.L. Sentence Length in Public Speaking, Ural Federal University, Russia, 2021. Available online: https:/ /github. com/Kototiapa/Sentence-Length-in-Public-Speaking.git (accessed on 25 July 2021).

39. Baronchelli, A.; Ferrer-i-Cancho, R.; Pastor-Satorras, R.; Chater, N.; Christiansen, M.H. Networks in cognitive science. Trends Cogn. Sci. 2013, 17, 348-360. [CrossRef] [PubMed]

40. Ferrer i Cancho, R.; Solé, R.V.; Köhler, R. Patterns in syntactic dependency networks. Phys. Rev. E. 2004, 69, 051915. [CrossRef] [PubMed]

41. Solé, R.V.; Ferrer-Cancho, R.; Montoya, J.M.; Valverde, S. Selection, tinkering, and emergence in complex networks. Complexity 2002, 8, 20-33. [CrossRef]

42. Solé, R.V.; Corominas-Murtra, B.; Valverde, S.; Steels, L. Language networks: Their structure, function, and evolution. Complexity 2010, 15, 20-26. [CrossRef]

43. Ferrer i Cancho, R.; Hernández-Fernández, A.; Lusseau, D.; Agoramoorthy, G.; Hsu, M.J.; Semple, S. Compression as a universal principle of animal behavior. Cogn. Sci. 2013, 37, 1565-1578. [CrossRef] [PubMed]

44. Shulzinger, E.; Bormashenko, E. On the Universal Quantitative Pattern of the Distribution of Initial Characters in General Dictionaries: The Exponential Distribution is Valid for Various Languages. J. Quant. Linguist. 2017, 24, 273-288. [CrossRef]

45. Shulzinger, E.; Legchenkova, I.; Bormashenko, E. Co-occurrence of the Benford-like and Zipf Laws Arising from the Texts Representing Human and Artificial Languages. arXiv 2018, arXiv:1803.03667.

46. Drożdż, S.; Oświęcimka, P.; Kulig, A.; Kwapień, J.; Bazarnik, K.; Grabska-Gradzińska, I.; Rybicki, J.; Stanuszek, M. Quantifying origin and character of long-range correlations in narrative texts. Inf. Sci. 2016, 331, 32-44. [CrossRef]

47. Kirkaldy, J.S. Thermodynamics of the human brain. Biophys. J. 1965, 5, 981-986. [CrossRef]

48. Swenson, R.; Turvey, M.T. Thermodynamics reasons for perception-action cycle. Ecol. Psychol. 1991, 4, 317-348. [CrossRef]

49. Kondepudi, D. Self-organization, entropy production, and physical intelligence. Ecol. Psychol. 2021, 24, 33-45. [CrossRef]

50. Barrett, N. On the nature and origins of cognition as a form of motivated activity. Adapt. Behavior. 2020, 28, 89-103. [CrossRef]

51. Guevara Erra, R.; Mateos, D.M.; Wennberg, R.; Perez Velazquez, J.L. Statistical mechanics of consciousness: Maximization of information content of network is associated with conscious awareness. Phys. Rev. E. 2016, 94, 052402-052411. [CrossRef]

52. Mateos, D.M.; Guevara Erra, R.; Wennberg, R.; Perez Velazquez, J.L. Measures of entropy and complexity in altered states of consciousness. Cogn Neurodyn. 2018, 12, 73-84. [CrossRef] [PubMed]

53. Perez Velazquez, J.L.; Mateos, D.M.; Guevara Erra, R. On a simple general principle of brain organization. Front. Neurosci. 2019, 13, 1106. [CrossRef] [PubMed]

54. Martyushev, L.M.; Seleznev, V.D. Maximum entropy production principle in physics, chemistry and biology. Phys. Rep. 2006, 426, 1-45. [CrossRef]

55. Martyushev, L.M. Entropy and entropy production: Old misconceptions and new breakthroughs. Entropy 2013, 15, 1152-1170. [CrossRef] 